\title{
An Investigation of the Economic Diversification of the Zambian Economy through Arts and Culture: A Case Study of Lusaka District
}

\author{
Paul Bernandicto Ngosa
}

Zcas University

Zambia

\begin{abstract}
This dissertation is to investigate the economic diversification of Zambian economy through art and culture. This investigation is conducted in Lusaka through a case study and the study used a mixed research methods approach which incorporate both qualitative and quantitative data and the case study approach is adopted in this study.
\end{abstract}

The study finds that diversification of the economy through art and culture has direct economic benefits include; increase in household income, increase in government revenue, increase in job creation and have multiplier effect on other sectors like tourism, education and health. The other findings is that, it increases and enhances social cohesion, rural development and rural financial inclusion, increase social capital and positive impact people's wellbeing, capability and self-sustenance.

The primary recommendation coming out of this study is that government of Republic of Zambia to take serious steps towards the pride of this sector. The government to formulate policies to end piracy and gazettes the rights of artist. Government to create schemes to empower these arts and culture groups and association. Lastly, constant reviewing and monitoring of policies of arts and culture industry. Reviewing the structure and mandate of ministry of arts and tourism for the sole purpose of diversifying of the economy in this sector.

The significance and value of this study is to remind and alert the government of the Republic of Zambia the potential of arts and culture industry in stimulating economic development, capacity, ability, and self-sustenance of the nation through economic diversification.

KEY WORDS: Economic Development, Employment, Household income, Government Revenue and Gross Domestic Product.

\subsection{INTRODUCTION}

This chapter provides an insight of the background of the study, and a refining of the research questions to have better understanding the present situation of arts and culture in Lusaka and its existing knowledge in Zambia and identifying the gaps. The aim of the study, research objectives and value of the study, its scope and research methodology used, data collection methods and analysis techniques and outline the dissertation structure layout.

\subsection{Background}

Zambia is one of the major producer of copper in Africa yet the economy of the country still underdevelopment and the only way to survive the present situation of global uncertainty is to diversify the economy to one of the most promising industry globally which is arts and cultural industry. Arts and culture contribute to national and household income (Art Council England 2015). As a matter of priority, Zambian government must encourage the diversification of Zambia's economy. It is the only viable way to survive the current environment of global economic uncertainty with the volatility of copper prices. It is crucial that government do not believe that copper provides an endless source of revenue. Zambian economy is mono-economy, depending on copper. The government have failed to diversify the economy for a long time now despite the country blessed with rich tradition and endowment of arts talents. The country continues to run a mono economy and copper as main source of government, household income, employment creation of which sooner or later copper will finish because of its non-renewable asset characteristic. Art can be defined in many ways and most times, Art is said to be a human skills and design, architecture and painting while Cultural described as things whose output have some symbolic values like fine art, film and craft, fashion and publishing, and jewellery design. The thesis will investigate whether the arts and cultural industry have multiplier effect on macroeconomics variables, the 
major constraints leading to failure by government diversify the economy in Zambia and general challenges the industry is facing. The study will then evaluate the economic benefit that can be accrued from the industry using macroeconomic variables and propose macroeconomic policies that government can adopted to boost the industry. This study will use quantitative research approach when analysing the data and the methodology will be descriptive research method of data collection.

Arts and cultural sector have been proclaimed as an answer for a wide range of issues Arts incorporated school educational program and improve students' academic performance (Fiske 1999, Remer 1990). Arts and culture revive neighbourhoods and advance monetary success (Costello 1998, Walesh 2001). Active participation in art enhances physical and mental prosperity (Keating 2002, Turner and Senior 2000). Arts and culture give an impetus to the making of social capital and the accomplishment of imperative network objectives (Goss 2000, Williams 1995). Art and culture attracts visitor and tourists visit country to attend arts and cultural events. They will spend straightforwardly on arts occasion and may likewise shop, eat at a nearby restaurant as well as remain in hotels in the country. To the degree that these visitor dollars are spent by arts and cultural association, the stores, restaurants and hotels - on local products goods and service, the dollars that is received in the economy will have multiplier consequences on the local economy. Arts and culture draw in inhabitants and businesses, the density of arts and cultural associations and commonness of art occasions may assume a job in pulling in occupants and business to relocate to communities by enhancing its image and making it more engaging. This is particularly valid for pulling in profoundly gifted, high-wage inhabitants, who will have a bigger monetary effect than less-talented individuals. Businesses, particularly those that utilize exceedingly prepared versatile staff, may consider location of craftsmanship activities when settling on area of business (Cwi 1980). The presence of arts and culture may work to enhance the effect of tax incentives and motivations for business (Costello 1998). High groupings of craftsmen as well as high-gifted specialists may deliver agglomeration impacts for the businesses particularly those in the faster developing creative enterprises (Walesh 2001). Arts and culture activities draws speculations or investment through enhancing national and community image, individuals may feel progressively sure about putting resources into that country or community.

\section{Research Problem and Justification}

Zambia has failed to diversify its economy fully in key sectors of the economy, one of the sector is arts and cultural sector which is the most promising sector for economic development all over the world. Government of republic of Zambia have not explored the full potential of this sector which could have contributed to nation domestic product growth, employment creation and earned foreign currencies through export of arts and cultural products, Household income and tourism.

\subsubsection{Research Aim}

This thesis aim to investigate the economic diversification of Zambian economy through arts and culture a case study of Lusaka district of Zambia.

\subsubsection{Research Objectives}

a) To determine the impact of Arts and Cultural Industry on the macro economic variables.

b) To investigate the effects of Arts and cultural industry have on non-macroeconomic variable.

c) To determine governments policy interventions on arts and culture for economic diversification.

\subsection{Research Questions}

a) How Does Arts and Cultural Industry impact macro-economic variables like employment, National income (Revenue) and Household Income in Lusaka district?

b) What effects does Arts and cultural industry have on non-macroeconomic variable or sectors like Education, Health, Community and Tourism Sector in Lusaka district?

c) How can the Government of Republic of Zambia use arts and culture to enhance economic diversification in Lusaka district?

\subsection{Significance and value of the study}

Art and Cultural industry are one of the emerging economy and the sectors has potential to boost and stimulate economic development.

\subsection{Scope of the study}

The study will concentrate on six forms of arts and cultural activities which are; Visual arts, Music festival and Craft arts . 
International Journal of Advances in Scientific Research and Engineering (ijasre), Vol 5 (5), May-2019

\subsection{Explanatory variables and Dependent Variables}

The independent variable is;

$>$ Arts and Culture ( Visual arts, Music festival and Craft arts)

\section{The dependent variables are:}

$>$ Macroeconomic variables ( Government Revenue, Employment, Household Income ,Education and Health)

Economic model $Y=X v+X c+X m f$

Where

$Y=$ Dependent Variables (Macroeconomic Variables)

$\mathrm{Xv}=$ Visual Art

$X c=$ Craft

$X m f=$ Music Festivals

\subsection{Methodology - research philosophy/deductive or inductive/qualitative or quantitative}

Methodology is the arrangement of standards of research, which controls the researcher to choose the kind of research technique which would be most suitable (Sim and Wright 2000). It is fundamental for the researcher to have a top to bottom comprehension of the understanding research procedure and the philosophical perspectives and presumptions which will shape the information (Hart 2008). The thesis was conducted through mixed method of qualitative and quantitative to appreciate and understand the economic diversification of the economy through arts and culture in Lusaka district of Zambia.

\subsection{Data collection and Analysis of techniques}

The study will utilize primary data and the data collection instrument will be a self-administered Questionnaire, and the researcher will self-administer questionnaires for primary data to all selected respondents. Data collected from the questionnaires was subjected to verification for consistency, uniformity and accuracy before being entered using a software package MS EXCEL. Descriptive statistics will be applied to help establish patterns, trends and relationships and to make it easier to understand and interpret the implications of the study. The thesis will measure the economic indicators such as employment, Government revenue and Household. The thesis also analyses the multiplier effect of this sector which will measure the ratio of change in output or production of all industries caused by one unit increase of arts and culture output. The thesis will also analyse the multiplier effect of tax revenue which will measure the ratio of change in tax revenue of all industries caused by one unit increase of the sector spending.

\subsection{Research Limitation}

This study like any other researches has limitations of time constraints and the data provided by the ministry of arts and tourism was not adequate and not all the artists were registered with Nation arts council as well as National arts association of Zambia. However, these limitation were addressed in the research and taken into consideration during the analytical and recommendation sections of the study.

\subsection{Chapter Summary}

The arts and culture have the potential to generate numerous benefits to the national economies. Through arts and culture the country have an opportunity to create employment, Generate tax revenue and stimulate local economies through tourism and exports of arts and culture products? However to realise these, the country should adopt strategies that support and strengthens the arts and culture industries and these includes offering incentives policies targeted at the arts and culture sectors, development initiatives, entrepreneur training, marketing programmes and public private partnership to encourage growth and invest in some creative cluster and leveraging the arts and culture to gain competitive edge in business. By diversifying the economy through arts and culture sector and incorporate it into development plans, a country can reap numerous benefits like economic benefits, social benefits civic benefits, health and education benefits and new tourism.

\section{LITERATURE REVIEW}

This chapter highlights and bring out theories of diversification, art and culture sectors both local and globally.it scrutinizes the information published and other study conducted of how art and culture impact the economy and how the diversification of the economy can be core engine to national development. The author will analyse various study carried out in the past to compare and to contrast their views and recommendation in reference to this study. 


\subsection{Art and Culture industry in Zambia}

Zambia is landlocked country with high trade and transportation coasts. Growth has not been inclusive and poverty in Zambia is widely spread, with 61.3 percent of the population estimated to be living below the national poverty line. Rural poverty at 74 percent is more than double the urban poverty rate of 35 percent. Sustained growth and continued political stability have produced only modesty improvements in livelihoods (Simpasa 2011). The effect of the economic growth on overall poverty reduction has been small, as much of the benefits of growth have accrued to those already above the poverty line. Growth has been primarily driven by mining, construction, and financial services and did too little to create jobs and expand opportunities beyond the relatively small labor force already employed in the industries. Diversification of the economy must be a priority of the country and efforts must be made to provide employment opportunities for the dislocated worker, with proper training made available to give these individuals the new skills they will need in a diversified economy (White 2014). Education of the workforce, with adult literacy programs and other education or training programs must be a priority and efforts to diversify in the region include focusing on the areas of arts and culture.

In Zambia, the literature review on arts and cultural industry may not be enough or difficult to find. However, there is overwhelming literature world wide of which Zambia share common values and economic benefits that come with development of arts and cultural industry. To develop this industry and benefits from its effects, policies and procedures should be clearly defined for safeguarding vulnerable citizens and firms for arts and artists (ace and NSPCC 2005), Government through the ministry of education should embark on the development of arts in the community (Cole 2011) and the right of the artists in the communities should be respected. To enhance occupation standards, it's important that art and culture are introduced and taught in schools (Keeling 2011). Government of the republic of Zambia under new curriculum introduced two career pathway which is academic and vocational to give its citizen survival skills as demonstrated by Freakley 2003 and identify why people involve themselves in arts (McCarthy 2001). Arts works impact best practices in people and accredited training institution for professionalism (Preston 2007). According to Scottish Arts council (2001) stated that there must be set standards and skills to be used when training individuals and encourages national accredited qualification. This is because accredited qualification will promote bespoke academic programme as thus, artists who begins their career in tender age tend to succeed more (Booth 2009). Arts and culture has been catalyst for social inclusion, diversification and play major role in economic development (Evans 2009) .However motivation is key to the success of that and motivated participants brings out best cultural practices (Fisher 2003) and this can only be done if policy makers formulate these policies which can enhance the arts practices to encourage the artists (Powell 2001). Arts and cultural activities if well explored in the today emerging economies and influence the education system positively (Robinson 2011). When the art and cultural is seriously involved in the communities and get appreciated which get results to safe environment and bring social benefits (Matarasso 1997). Government recognition and intervention in arts and cultural activities encourages social cohesion which could lead to Public Investment (Beltiore 2002). However, Government should be in position of understanding the cultural diversity so that best policies are formulated to favour the industry in the economy (Martland 2006) and these cultural diversity should not contradict with each other (Mirza 2009).

Diversification of the economy is the only way to survive and thrive the present global economic uncertainties and persistence of price fluctuations of major exporting product on the world market, (Suberu 2015). Diversification to art and cultural sector increases nation GDP (Tim 2014). There are a lot of theories on creative industry which comprises of arts and culture industry. However, major theories on this study is restricted to theory of value, Creative economy and culture in economic development (David 2001). Arts and culture as economic asset which is mainly a service industry work closely with competitive economies of production and countries like China and Korea have seen massive economic growth through innovations and inversions of arts and culture (NGA 2008). Arts and Culture industries have direct impact on investment, job creation National income and multiplier effect on tourism (NGA 2008). According to NGA 2003, Arts and culture stimulate international trades and business development strategies. Art and culture is precisely the medium through which individuals and firms express their abilities to fulfil themselves and is therefore, an integral part of development (UNESCO 2009).

Arts and Culture briefing paper by Christine and Ann 2011 stated that in the modern world today strategies for national economic development has shifted from firm based approach to human capital based approach. Arts and culture impact communities 'wellbeing and increase social capital and cohesion (Joshua 2002). Art as an export industry and according to Angus 1999, arts and culture has direct benefits to physical health of individuals (Buklien 2000). Arts and culture serves as a springboard for sustainable development and industrialisation of national economy (Irivwieri 2009). Arts and culture transforms education systems (Obrien 2004), and according to Wenger 1999 evaluated the quality of participatory in arts bring about knowledge by which people know what they want and improves social norms. Information shared brings about the good participation, artist and culture act as a mediator in delivery and evaluation issues across (White 2010). Arts and culture are catalyst for social inclusion, diversity and urban regeneration. Powell 2001 emphasised to policy makers and planners to include arts in their planning and budget. There are both positive and negative effect of arts and culture on the society (Belfiore and Benet 2010) and Arts act as advocacy and effective communication (DCMS 2007), Matarosso 1997 evaluated arts and culture to improve personal development, social cohesion, self-empowerment and self-identity. Introducing arts in school also helps the teachers and pupils to develop their skills 
(Dust 1997), Music education (Henley and Darren 2011) and (department of education 2011) in England. Arts and culture illuminate the inner lives of people and enrich world emotions.

\subsection{Employment and Revenue}

Zambia's labour force increased by $14 \%$ from 5 million in 2008 to five. 8 million in 2012 and also the 2014 Labour Force Surve y estimates the labour force 6.3 million. Total employment grew by $11.3 \%$ from 5.3 million in 2012 to 5.9 million in 2014 , representing associate employment-to-population magnitude relation of seventy 1.9 percent. About 4.9 million persons, representing $84 \%$ of the utilized, were within the informal sector. The most challenge is to extend the number and quality of productive employment in the least levels of the economy and all told components of the country, to scale back financial condition and reach comprehensive economic process.

In 2014, over $80 \%$ of the utilized in Zambia were within the informal sector. However, the arena was characterized by low levels of productivity, capital investments and technology, thereby providing restricted prospects to contribute to national development and ultimately up the quality of living of the bulk of the folks. Overall, the per centum was $7.4 \%$ of the overall labour force. Urban per centum was $11.5 \%$ whereas rural per centum was 4.2 percent. Throughout the amount beneath review, youth state remained one in all the largest challenges. Of the 3,812,923 youths within the labour force, 400,810 were idle, representing a youth per centum of ten.5 percent. The male youth per centum was higher at $12.2 \%$ than the feminine youth per centum at 9.1 percent. The agricultural youth per centum was 6.4 percent, compared to 15.2 urban youth per centum.

The majority of the folks operating within the informal sector were classified as operating poor with low levels of financial gain, restricted or no access to Social Security and different core labour standards as prescribed by the International Labour Organization. Additionally, a big range of the operating population is freelance, principally in subsistence agriculture or smallscale and sometimes fragile businesses.

Art and cultural industries are such industry if well explored has potential to create wealth and employment in the country and boost foreign reserve, it will also contribute to the growth of GDP which have a multiplier effect on economic growth and development of the Nation. Globally, the arts and cultural industries have been seen to be powerful global economic engine in creating employment and generate income.in 2015 the industry generated income US\$1.3 Trillion and accounted for more than $7 \%$ global GDP. In Tanzania, the study conducted by Kitime in 2001 reviewed that the country was able to make US\$12 million each year from music and video businesses.in England the report for arts council England 2015 by CEBR showed that in 2011 the country made 12.4 Billion Pound from arts and cultural sectors and in 2013 the revenue increased to15.1 Billion pounds and contributed to employment which increased by $4 \%$ from 123,000 people to 128,000 people between 2010 and 2013. the industry contributed 7.7 Billion pounds of gross value added to the country in 2013. Cultural creativities and Arts have been massively used in South Africa to boost economic growth and job creation. According to the report of Mzansi's Golden Economy which reviewed that economic growth and development of South Africa have been partly supported by arts, cultural and heritage sector. In 2014 the study carried out by Cultural and Creativity in South Africa reviewed that jobs were created between 162,809 to 192,410 jobs which is $1.08 \%$ to $1.28 \%$ and it contributed about $2.9 \%$ to GDP. In USA arts and culture contribute about US\$704. 2 Billion In 2013 to the national economy. Arts and culture are a modern global economic engine which generated income about US\$1.3 trillion in 2005 globally, culture industries accounts for not less than $7 \%$ as at 2015 . Countries that have diversify their sector in arts and culture industries like United States of America, India and Nigeria have benefited so much from this sector, the study carried out by Kabanda in 2014 indicates that Bollywood turned 100 in 2013. Based in Mumbai, India, it is considered the world's largest movie industry ( in terms of production ) Estimated to produce 1000 films annually and generated USD \$3 billion in 2011 and estimated at a 10percent growth rate per year. International business development Hollywood is based in California, United States and about 400-600 films produced annually, Movies and videos industries contributed USD\$47 billion (value added) to the USA economy (2011). Hollywood and the video industry employed about 310,000 workers (USD\$25 billion in compensation). Nollywood is a Nigerian-based industry estimated at USD $\$ 800$ million and employs about 300,00 people the movie production cost between USD \$15,000 to USD\$30,000 and over 900 movies produced annually translated to second largest industry in terms of production adding to 1.4 percent to Nigeria's GDP of USD\$522.6 billion (2013) (Kabanda 2014), and the art and culture industry play significant role in reinforcing tourism at regional and local levels; they offer in this way an opportunity for economic diversification and smart specialization, as well as raising the attractiveness of the regions. Cultural and creative industries are also directly contributing to the jobs and growth of tourism sector (EU 2012). Spending by arts audiences directs USD $\$ 102.5$ billion to local businesses, like all industries, spending by arts organizations has a measurable economic impact. Unlike most industries, however, the arts generate a bounty of event-related spending for local businesses- dollars that land the pockets of local establishments such as restaurants, retail stores, hotels, and even the local babysitters. These expenditures translate to average spending of $\$ 31.47$ per person, per event, beyond the cost of admission (Cohen 2017).

\subsection{Economic Diversification}

The diversification of the economy will help insulate the economy will help insulate the community against future economic downturns and develop a strong entrepreneurial culture so that new companies and ideas will continuously emerge and better insulate the region from external economic forces. The region will also grow economic strength in globally competitive industries 
which including advanced manufacturing, manufacturing-related producer and distribution service, entrepreneurial enterprises (Mark White 2014).

In fact, the income share of the bottom $40 \%$ fell from 2003-2010. Thus, for Zambia, economic diversification remains an essential objective to deliver more inclusive growth in the face of declining prices for copper, and to create employment for its fast growing, Urban and youthful population. (Simpasa 2011). Zambia have abundant deposits of copper and copper is the main export product and the income levels per capital income is just over US\$3,800. Fifty years ago, both countries produced similar amount of copper. Though Zambia have showed higher levels of production than other countries, it has remained stagnant, although there has been a recovery since 2000. Copper is about $80 \%$ of Zambian exports (Simpasa 2011). Diversification of the economy is paramount important in the economy by not chiefly dependent on the oil sector as the mainstay and the largest contributor to the total government revenue and GDP. Economic diversification is vital to countries' long term economic growth. Too often, country lack clear policy guidelines on how to diversify, and policymakers have limited understanding of why diversification is important. Diversification is driven by human capital development which is the starting point, driving force and sustaining force (Onodugo Ifeanyi Chris 2015)

Diversification makes the country less vulnerable to term of trade shocks and this positive terms -of-trade shocks can be channeled into economic growth. The trade diversification can reduce movement in exchange rate especially extensive diversification thus preventing it from long run equilibrium and this will go a long way in bringing about stability in the economy. This can be regarded as one of the channel through which trade diversification enhances growth (Aleg 2018). The country must diversify in both directions to maximize the benefits of macroeconomic environment frequently disturbed by exchange rate movement (Aleg 2018). However it should be supported by a strong, growing, sustainable economy which the goal of every nation in the world. A sustainable economy enhances the nation's standard of living by creating wealthy and jobs, encouraging the development of new knowledge and technology, and helping to ensure a stable political climate (Rabin Abouchakra 2008). Arts and culture industries produce many different types of spillovers on the economy and society as the whole, from inspiring and nurturing creative and innovative entrepreneurism to designing new public service transportation and promotes a more qualityoriented tourism in regions and cities to helping social regeneration of deprived areas and innovative forms of teaching, from design thinking in all types of setting to the use of culture and creativity as a management tool for improving working relationships in companies (EU 2012). The art and cultural industry play a significant role in reinforcing tourism at regional and local levels; the offer in this way an opportunity for economic diversification and smart specialization as well as raising the attractiveness of the region s. Cultural and creative industries are also directly contributing to the jobs and growth of tourism sector (EU 2010). Americans for the arts' fifth study of the nonprofit arts and culture industry's impact on the economy indicates that are and culture industry provide both cultural and economic benefits to the community (Cohen 2017). In 2015, the nation's nonprofit art and cultural industry generate $\$ 166.3$ billion of the economic activity $\$ 63.8$ billion in spending by art and cultural organizations and an addition $\$ 102.5$ billion in event related expenditures by their audiences. 4.6 million Full time equivalent jobs' $\$ 27.5$ billion in federal, state and local government revenue, \#96.1billion in house hold income (Cohen 2017). Nonprofit art and cultural organization are good are good business citizens. They employ people locally purchase goods and services in the community, are members of the chambers of commerce, and are involved in the marketing and promotion of their regions. The largest body of research examines the effects of participation in culture, but a significant portion of this evidence also document positive impacts on well-being and social cohesion, as well as the development of social capital. These types of impact also feature prominently in the literature on culture's effects on health and educational (Jeannette 2017)

Art and cultural heritage improves the quality of healthy on every corner of the world and takes into account how both tangible and intangible heritage contributed to sustainability as measure in four domains: economic, social, cultural, and environmental (Consortium 2015). The social domains includes social cohesion, community, participation, and continuity of social life, but overlaps with the cultural domain in the creation of identity and sense of place; and with the economical domain in the areas of education, knowledge and skills, place branding, contribution to the labor market, and regional competitiveness (Consortium 2015). The co-existence of different ways of life and values, make space for equal participation, highlight diversity and inclusion, and respect the rights of all citizen groups including cultural rights. This set of socially oriented cultural policies is intertwined and linked with other policies that negotiate memories and identity, a sense of place, creative practices, economic development, nature conversation, and sustainability awareness but it should be in line with policy makers who should pursue vigorously both intensive and extensive trade diversification in other to propel economic growth and trade diversification can guarantee stable exchange rate in the economy (Dessein 2015). Therefore, government should open up more sector of the economy for international transactions and increase number of trading partners across regions of the world (Aleg 2018)

A successfully diversified economy is expected to reduce the economy exposure to adverse external shocks and macroeconomic instability (Mobarak 2005) though Moore and Walkes (2010) argued that diversified production structures tend to have lower volatility on output, consumption, and investment which ultimately ensure macroeconomic stability. Having a diverse economy that is based on a wide range of profitable sectors, plays a key role in a sustainable economy, to appreciate this identification of a link between economic diversity and sustainability, and economic diversification can reduce nation's economic volatility and 
increase its real activity performance. Furthermore, there are metrics that policymakers can use to measure the key economic dimensions and ways that they can promote their nations long-term economic health and stability (Rabih Abouchakra 2008).

According to IEG report (World Bank 2017), Economic diversification is a key element of economic development in which a country moves to a less concentrated production and trade structure. Lack of economic diversification is associated with increased economic vulnerability such that external forces can undermine the development process. Diversification help manage volatility and provide a more stable path for equitable growth and development. Successful diversification is all the more important now in the wake of stagnating global growth and the imperative in many developing countries to increase the number and quality of jobs and the role of government in reducing barriers to diversification and in addressing market failures that limit the movement of resources to new activities as always surrounded discussion of diversification strategies. Despite its apparent economic benefits, not all developing countries have pursued diversification and fewer still have been successful in their efforts to overcome the dominance of natural resources and primary commodities IEG report.

The success of diversification will depend on the mix, sequencing, and timing of investment, policy reforms and institution building, and on their consistency with the underlying assets and related comparative advantages of the country. Investment in skills, infrastructure, institutions and governance quality and increase the likelihood of success of diversification but are in turn affected by the extent of diversification. (Shahid 2016). There are multiple paths to successful diversification. In countries at very low levels of economic development the priority is to get the basic right to support gradually the diversification of the economy. As countries develop, multiple diversification path may become available. Malaysia, for instance, was previously a primary based economy. Africa exports are less diversified than the rest of the world despite Africa being the home of some of the world's most concentrated export baskets, while some African country has been successful in diversifying their exports by bring more firms and more products to the global market in traditional and new markets and sectors, others have lagged behind.

\subsection{Chapter Summary}

Assemble limits in social zones through instruction and preparing in human expressions, expressions organization, legacy the executives and social business. Put resources into social businesses to produce new and indigenous types of work and fares, to help in the enhancement of economies, and to strengthen and grow social certainty and ties with abroad networks. Fortify discussions among Governments and social enterprises so as to adjust government approach on culture and exchange, industry, the travel industry, training, licensed innovation insurance and different areas. Secure the licensed innovation of Small Island creating States against robbery in the music, distributing and other inventive ventures, and fabricate the limit with regards to rights the executives and licenses, trademarks and copyright organization in Small Island creating States to ensure all types of imaginative development and raise open consciousness of those issues.

Enhance institutional limit with regards to the support, advancement and promoting of social items, administrations and protected innovation, including copyrights. Enhance access to capital and credit, specifically in the zones of advancement financing and market improvement gifts for little and medium-sized endeavours and the foundation of culture bolster assets in little island creating States locales.

Include people group in arrangement making to defend their social legacy, including distinguishing what merits insurance and who claims it. Enhance the administration of social and characteristic legacy destinations and guarantee the openness of such legacy to all and its financially savvy support.

Create associations among Governments and common society for economical legacy the executives. Support and reinforce network limits in asset the executives and administration. Create projects to record conventional information and save standard social qualities, customs and practices. Instruct and transmit customary network esteems and related neighbourhood and indigenous information in essential training. Record and archive indigenous dialects as a way to help their methodical consolidation into school educational module and support distributing in indigenous dialects

It is comprehended that social essentialness is a noteworthy driver in building prosperous and fruitful urban areas. To this end we are setting out on a city social arranging procedure to use nearby social resources and assets for supporting financial.

\section{RESEARCH METHODOLOGY}

The purpose of this chapter is to illustrate the methodology used to select participants, the tools and approach used to collect the data, the sample size and how it was selected. The chapter incorporates the research methodology of this thesis. Furthermore, the researcher gives the outline of research methods, Research approach, data collection methods, sample selection, the process of the thesis and how the data analysis will be conducted in this thesis. Chapter will also outlines the ethical considerations and the limitation of the research. The research conducted in respect of this dissertation was not new. This is because various study have been conducted in this category of the economic impact on macro and non-macro-economic variables and various past scholarly research exist with respect to the arts and culture industry in advancing and overseeing economic benefits of this sector ( Langos 2014). So as to fulfill the goals of the thesis, a subjective research was held. The fundamental normal for subjective research is that it is generally suitable for little examples, while its results are not quantifiable. Its essential leverage, which likewise comprises its fundamental contrast with quantitative research, is that it offers a total portrayal and examination of an research 
subject, without constraining the extent of the research and the nature of participant's response (Collis and Hussey 2003).However, the viability of subjective research is vigorously founded on the aptitudes and capacities of analysts, while the results may not be seen as solid, since they for the most part originate from specialist's personal decisions and understandings. Since it is progressively proper for little examples, it is likewise dangerous for the aftereffects of subjective research to be seen as mirroring the assessments of a more extensive populace (Bell 2005).

\subsection{Research Paradigm}

In this case study, an interpretivists approach is embraced. This relies upon the researcher's deciphering different components of the research results. This spotlights on importance of the phenomenon being talked about and along these lines, it can utilize numerous techniques so as to reflect distinctive parts of the issue. The interpretivists approach expresses that individuals are extraordinary and can have diverse perspectives on a similar occurrences (Kumar 2011). Consequently, the observatory part of interpretivism was picked, particularly that it is additionally founded on the inductive end. It is by watching the subject that the respondents could give answers to the survey. The other methodology of positivism was not proper for this situation as it would have required playing out a logical ways to deal with find the solutions to the examination questions (Goldkuhl 2012). Interpretivism is mainly associated with Max Weber (Crotty 1998) and Alfred Schultz (Pring 2000).Interpretivists state that reality is multi-layered and complex. They believe that people are Creative and actively construct their social reality. They further note that the social world should be studied in the natural world, through the eyes of the participants, without the intervention of the researcher (Cohen et al 2003)

\subsection{Ontology and epistemology}

Interpretivists hold a realist, anti foundationalist ontology. Relativism is the view that reality differs from person to another (Guba and Lincoln 1994). Interpretive researchers believe in multiple realities (Crotty 1998; Pring, 2000) and that reality is socially constructed. Epistemologically, interpretivists adhere to a subjectivist view in that subjective meanings and Subjective interpretations have great importance (Pring, 2000). Crotty (1998: 79) states that the Object "cannot be adequately described apart from the subject, nor can the subject be adequately Described apart from the object." Therefore, the relationship between the knower and the subject to be known is not of detachment, but rather of involvement, interaction. In presenting the tenets of the interpretive paradigm, Grix (2004) writes that according to Interpretivism, the world is constructed through interaction of individuals. The natural and social worlds are not distinct and researchers are part of that social reality and are not detached from the subjects they are studying.

\subsection{Inductive and deductive methodologies}

Deductive methodology attracted from general to specific, while inductive is characterized as a methodology attracted from specific to general. The study is both inductive and deductive in nature as the methodology is done from the particular to general and general to specific perspective. The inductive methodology of this study was finished by dissecting data drawn from actualities dependent on the theory and research destinations. The inductive certainties were drawn from input review and whole investigation. The deductive actualities were drawn from existing literature looking at connections between study realities and existing literature certainties. (Scratch and Lee 2008)

\subsection{Research Approach}

To analyse how arts and culture industry stimulate the economic development using the macroeconomic indicators in the country, the researcher will get information and data from arts and cultural departments, Central statistics office, Cultural groups, individual artists, Music and film production enterprises, video production enterprises and Ministry of tourism. The macroeconomic indicator includes; Revenues to government and arts and cultural sector and individual artists and cultural groups, cost of production, employment creation and establish the arts and cultural industry multiplier effects on other sectors of the economy. The researcher will adopt both qualitative and quantitative research method this is because it's not only all economic benefit from arts and cultural industry that can be quantified or numerically proved and the research approach adopted would be abduction approach to research which combine the induction and deduction approaches where the data develops the theory and test it with the same data again (Kunin 2013). The research approach that was pursued for the motivations behind this thesis was the inductive one. As indicated by this methodology, the researcher start with explicit perception, which are utilized to produce generalized theories and conclusion drawn from the research. The main reason behind possessing the inductive methodology was that it considers the setting where investigate exertion is dynamic, while it is likewise most proper for little examples that create subjective information. In any case, the primary shortcoming of the inductive methodology is that it produces generalized hypotheses and decisions dependent on few perceptions, consequently the dependability of research results being under inquiry (Denzin and Lincoln 2005).

\subsection{Study area}

This study was conducted in Lusaka district, which is the capital and largest city of Zambia, as well as its chief administrative, financial, and commercial centre. Lusaka is one of the fastest-developing cities in Southern Africa. The City of Lusaka is situated in the central part of Zambia on the Central African Plateau and lies at an altitude of 1280m above sea level. The co-ordinates for 
Lusaka are 280-10' east of the Greenwich meridian and 150-30' south of the Equator. The district has a surface area of 360 square kilometres. Lusaka has a superb climate, with warm sunny summers, interspersed with cooling thunderstorms and mild winters with ample sunshine. The average maximum daytime temperature in January is $79^{\circ} \mathrm{F}\left(26^{\circ} \mathrm{C}\right)$, dropping to an average maximum of around $73^{\circ} \mathrm{F}\left(23^{\circ} \mathrm{C}\right)$ in July. It can get hot between October and March if there's no rain. Average annual precipitation is 33 inches $(836 \mathrm{~mm})$.

\section{7 . Population}

The target population includes visual arts, music festivals and craft arts.

Table 1: Shows the target population.

\begin{tabular}{|l|l|}
\hline Category & Population \\
\hline Craft arts & 400 \\
\hline Visual arts & 400 \\
\hline Music Festivals & 200 \\
\hline Total & 1,000 \\
\hline
\end{tabular}

Source: Ministry of Arts and Tourism (2018)

\subsection{Sample size}

In this study, we will use stratified random sampling method by selecting $10 \%$ of the total population (Mugenda and Mugenda, 1999). According to Kothari, (2004), $10 \%$ of the sample size is enough to conduct a research. This will give us a total of 100 respondents which is assumed to be a good representation of the target population. We will use the formula below to calculate the sample size $(\mathrm{n})$ :

Where:

$$
n=\frac{Z^{2} \times p \times q \times N}{e^{2} \times(N-1)+Z^{2} \times p \times q}
$$

$\mathrm{p}=$ sample proportion, $q=1-p$; we take $\mathrm{p}=0.5$

$\mathrm{Z} \alpha / 2$ : normal reduced variable at 0.05 level of significance $\mathrm{z}$ is 1.15

$n=$ size of sample.

$\mathrm{N}$ : size of population which is the number of SMEs

e: margin of error considered is $10 \%$ for this study.

$\mathrm{Z} \alpha / 2$ : normal reduced variable at 0.05 level of significance $\mathrm{Z}$ is 1.96

$$
\begin{gathered}
n=\frac{1.15^{2} \times 0.5 \times 0.5 \times 1000}{0.1^{2} \times(1,000-1)+1.15^{2} \times 0.5 \times 0.5} \\
=100
\end{gathered}
$$

Table 2: Shows the table of the sample population.

\begin{tabular}{|l|l|}
\hline Category & Population \\
\hline Craft & 100 \\
\hline Visual arts & 100 \\
\hline Music Festivals & 100 \\
\hline Total & 300 \\
\hline
\end{tabular}

\subsection{Sampling procedure}

Contrary to positivists who rely on randomization, interpretivists use purposeful sampling and select individuals and sites that are information rich (Cresswell 2008). Interpretive researchers rely on various methods to collect qualitative data. Creswell (2008) categorized Qualitative data into four categories: observations, interviews and questionnaires, documents and audiovisual materials. In terms of preference and usefulness, Punch (2009) states that "interview is the most prominent data collection tool in qualitative research." One of the reasons for this merit is underpinned to the flexibility of the interview as a tool since researchers may choose on whether to design structured, semi-structured, unstructured interviews; or whether to triangulate and use any two or all of them in one study. This means that researchers choose the type of interview that is aligned with the purpose of the study and the research questions. The methods of data collection that interpretive researchers employ enable them to build a relationship of trust with the subjects; for example, participant observers who opt for prolonged engagement in natural settings build close relationships with their subjects. They may use introspective methods (Dornyei 2007) which may enable them to achieve deeper understanding of the phenomenon under their interrogation; their emotions, experiences as well as perceptions of the subject matter under investigation

The research sampling procedure to be used in this study will be the probability sampling. By definition, probability sampling is a sampling technique where the samples are gathered in a process that give all the individuals in the population equal chances of 
being selected. In this technique, the population is stratified into strata's and sample items are selected from each stratum. The justification for using such a research sampling technique is that this procedure is convenient in that it does not consume a lot of time and it is cheap to conduct considering the limited time and funds available to follow all managers of SMEs in their various shops which wouldn't have guaranteed finding most of them. The strategy for purposive sampling was utilized to build up the sample of the research under discussion. As indicated by this strategy, which has a place with the class of non-probability sampling strategies, sample members are chosen based on their insight, connections and aptitude in regards to research topic ( Langos 2014).The sample individuals who were chosen had extraordinary association with the wonder under scrutiny, adequate and important work involvement in tarts and culture industry, dynamic contribution in a few the arts and culture industry activities and organizations, and in addition demonstrated research foundation and comprehension of crude information concerning goals (Langos 2014).

\subsection{Data collection method}

The study will utilize primary data. The method of data collection was self-administered questionnaires which were distributed to various institutions like ministry of tourism, arts and culture and central statistics office as source of information. Data were collected from national art council of Zambia, ministry of arts and tourism, department of cultural affairs, Zambia association of musicians, Individual music, and dance and drama groups. A total number of 100 respondent representing creative activities were covered in this study of which 80 were in privately sponsored and 20 publicly sponsored.

The data collection instrument was a Questionnaire, (see Appendix 1). The researcher will self-administer questionnaires for primary data to all selected respondents. The advantage of self-administered questionnaire is that there is direct contact among questioners and respondents (Langos 2014).

Content investigation was utilized to examine the information which was assembled from individual meetings. As indicated by Moore and McCabe (2005), this is the sort of research whereby information accumulated is ordered in topics and sub-subjects, to have the capacity to be practically identical. A fundamental preferred standpoint of substance investigation is that it helps in information gathered being diminished and streamlined, while in the meantime creating outcomes that may then estimate utilizing quantitative procedures. Additionally, content examination enables to specialists to structure the subjective information gathered in a way that fulfils the achievement of research goals. Be that as it may, human mistake is exceedingly engaged with substance examination, since there is the hazard for analysts to misconstrue the information assembled, consequently creating false and temperamental ends (Krippendorff and Bock 2008)

\subsection{Data processing and Analysis}

Data collected from the questionnaires was subjected to verification for consistency, uniformity and accuracy before being entered using a software package MS EXCEL.

The questionnaire is the main instrument for collecting data in survey research. Basically, it is a set of standardized questions, often called items, which follow a fixed scheme in order to collect individual data about one or more specific topics (Lavrakas 2008). Below is diagram showing the questionnaire process: source, https://en.wikipedia.org/wiki/Questionnaire

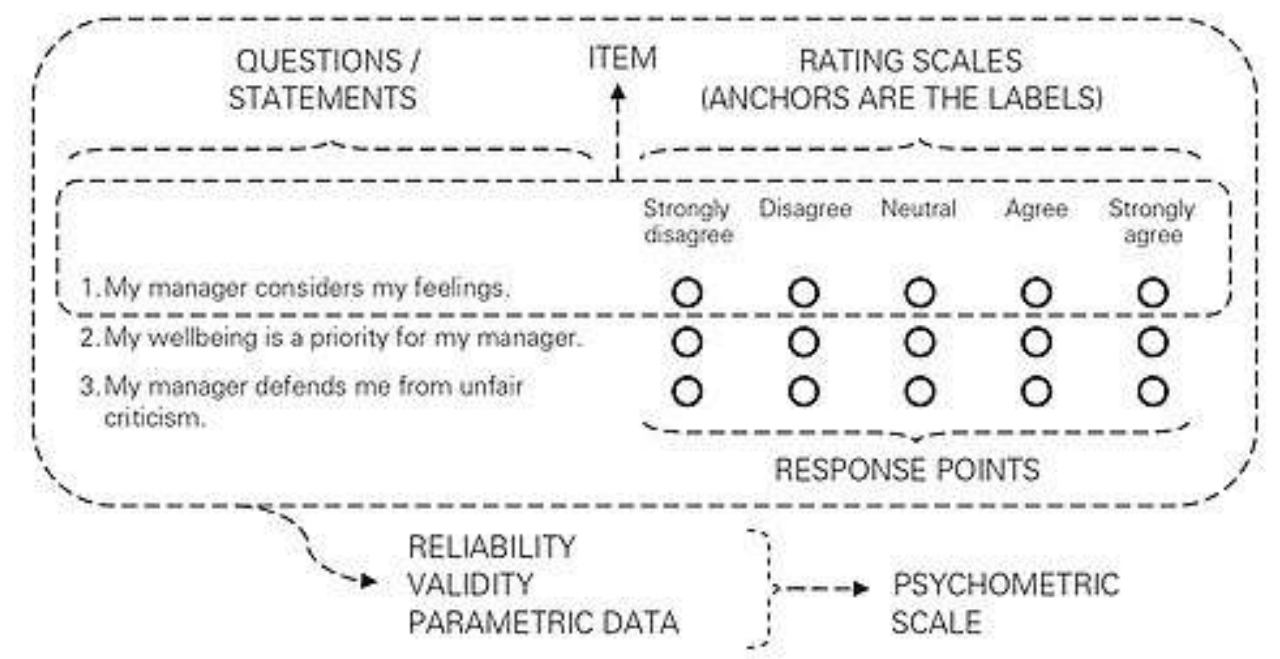

Descriptive statistics was applied to help establish patterns, trends and relationships and to make it easier to understand and interpret the implications of the study. The results will be presented using frequency tables and graphs, Pie charts and tables. 


\subsection{Research Design}

The research technique connected for this situation is the mixed method strategy. Mixed method strategies explore is an approach for leading research that includes gathering, examining and incorporating quantitative and qualitative research (McKim 2017). In its quintessence, mixed method techniques look into selecting, analyzing, and interpreting quantitative and qualitative information in a solitary report (Kumar 2011). Interpretive researchers use different methodologies such as case studies, phenomenology, and Ethnography. Denzin and Lincoln 2008 state that "qualitative researchers deploy a wide range of interconnected interpretive methods, always seeking better ways to make more understandable the worlds of experiences they have studied." Interpretivists' methodology aims at exploring and understanding phenomenon inductively. Interpretivists believe that the "social world can only be understood from the standpoint of the individuals who are part of the ongoing action being investigated" (Cohen et al 2003).

\subsection{Ethical considerations and Access issues}

Researcher will comply and act ethically and promote ethical behaviour during the study. The researcher will seek authority from relevant authority when collecting information and will always ask for permission and consent from target groups or participants and upheld high levels of confidentiality. The researcher will ensure that the physiological and physical well-being of the participants in the research are not negatively affected during the study. The researcher will not interfere with the works of other researchers or undermine and cause any harm. In this study the researcher will respect the autonomy of the participants and the consent will be always sought and that the information collected will be treated confidential, the researcher will not decide on the individual responses but will considers the general response to make comprehensive conclusion.

The study was liable to certain moral and ethical issues. As it was referenced before, all members revealed their composed acknowledgment with respect to their participation in the research, through a marked Consent and Briefing Letter. In the meantime, sample members were requested to sign a Debriefing and Withdrawal Letter. The aim of the two letters was to promise members that their engagement in the research is willful and that they were allowed to withdraw from it anytime and for any reason. The participants were completely educated with respect to the targets of the investigation, while they were consoled that their answers were treated as secret and utilized just for scholarly purposes and just for the motivations behind the specific research (Langos 2014).

\subsection{Credibility of Research}

Research integrity identifies with the execution of research to the most noteworthy principles of polished methodology and thoroughness, and to the exactness and truth of the research record in distributions and somewhere else (Krstic 2016). The data sources collected from Craft arts, Visual arts and Festival music were triangulated. Therefore, the research trustworthiness is guaranteed by triangulation of information accumulation and the suitably chosen instruments that guarantee honesty. Information triangulation is the utilization of different strategies or information sources in subjective research to build up an intensive comprehension of Phenomenon (Carter et al 2014). Triangulation likewise has been seen as a subjective research technique to test legitimacy through the combination of data from various sources during the time spent clarifying one parameter (Saunders et al 2009).

\subsection{Chapter three summary}

Chapter three demonstrated that the research is absolutely qualitative and quantitative in nature. Embracing essential and auxiliary research philosophy and simply utilizing inductive and deductive methodologies. This section likewise features that the fundamental instrument utilized in essential information accumulation is the questionnaire.

\section{RESEARCH FINDINGS AND ANALYSIS}

This chapter focuses on demonstrating the results of the study that was attempted by the techniques depicted in chapter three above. The Limitations thereof and results got are depicted in this section and a critical assessment/examination of the outcomes acquired, and huge clarification of discoveries is additionally included. The research analysis was led through distinct investigation. With the excel software tables, the research key results and examples were exhibited in graphical (bar charts and pie Charts) and pattern shape. These research discoveries are aimed at addressing the research questions that have been raised in order to solve the research problem.

\subsection{Findings Research Question one: impact of Arts and Cultural Industry on the macro economic variables.}

\section{CRAFT ART}

The researchers started by analysing the impact of craft art as a component of arts and culture industry on macroeconomic variable which include ; employment, Government revenue, Household income and its multiplier effect on the economy.

The researcher first brings out the craft works from various market where the data was collected from. 
International Journal of Advances in Scientific Research and Engineering (ijasre), Vol 5 (5), May-2019
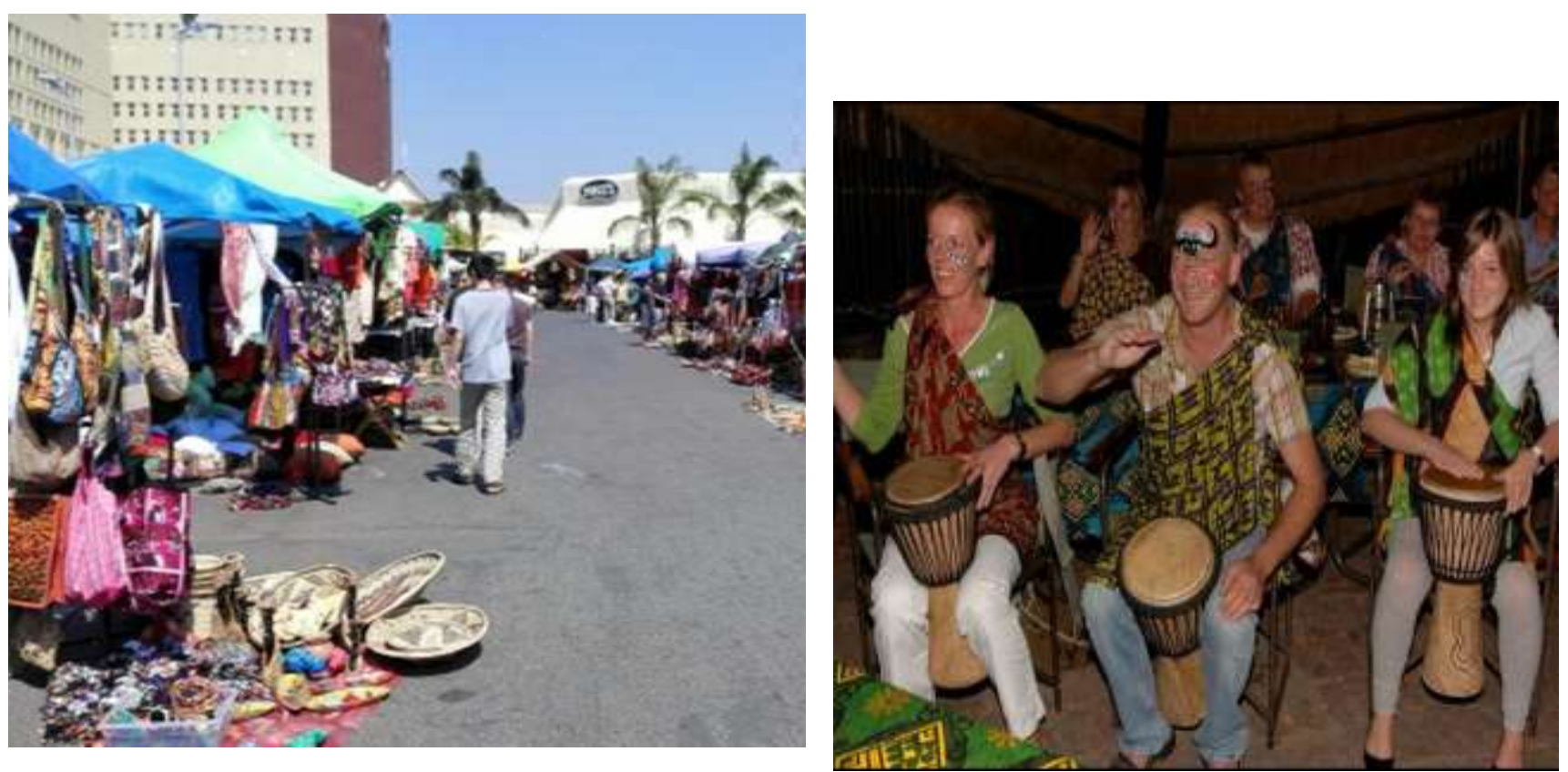

Figure 1: Craft activities in Lusaka at Arcades Sunday Market

This market sells a lot of craft which include; the hand craft, art piece and prints, precious stones jewellery and also carved animals.

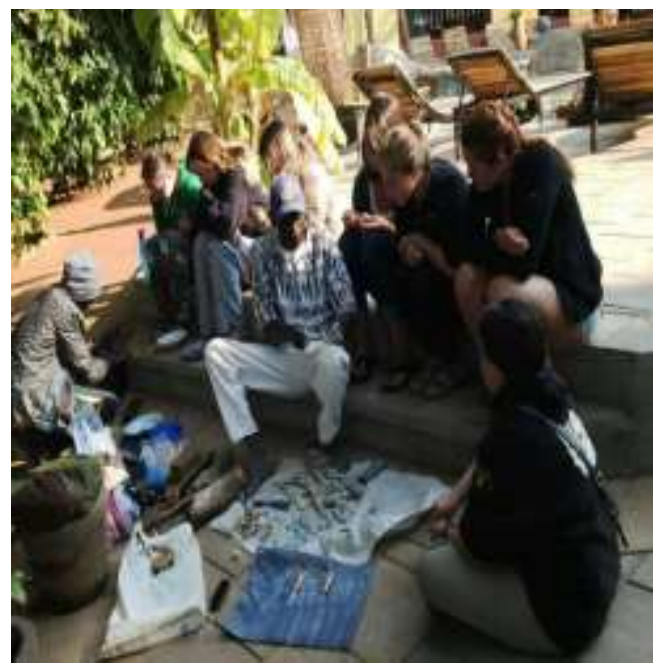

Figure 2: Craft activities in Lusaka by tourists

Zambia is one of the tourist nation of choice and blessed with creativity talent which tend to attract foreign and local tourists. However, as indicated by the research topic, this is only conducted in Lusaka district and the pictures above were obtained in Lusaka at arcades Sunday market.

Craft arts from the data collected shows to be the second highest of the proportional of employment among the three study area of craft, visual and music festivals. 


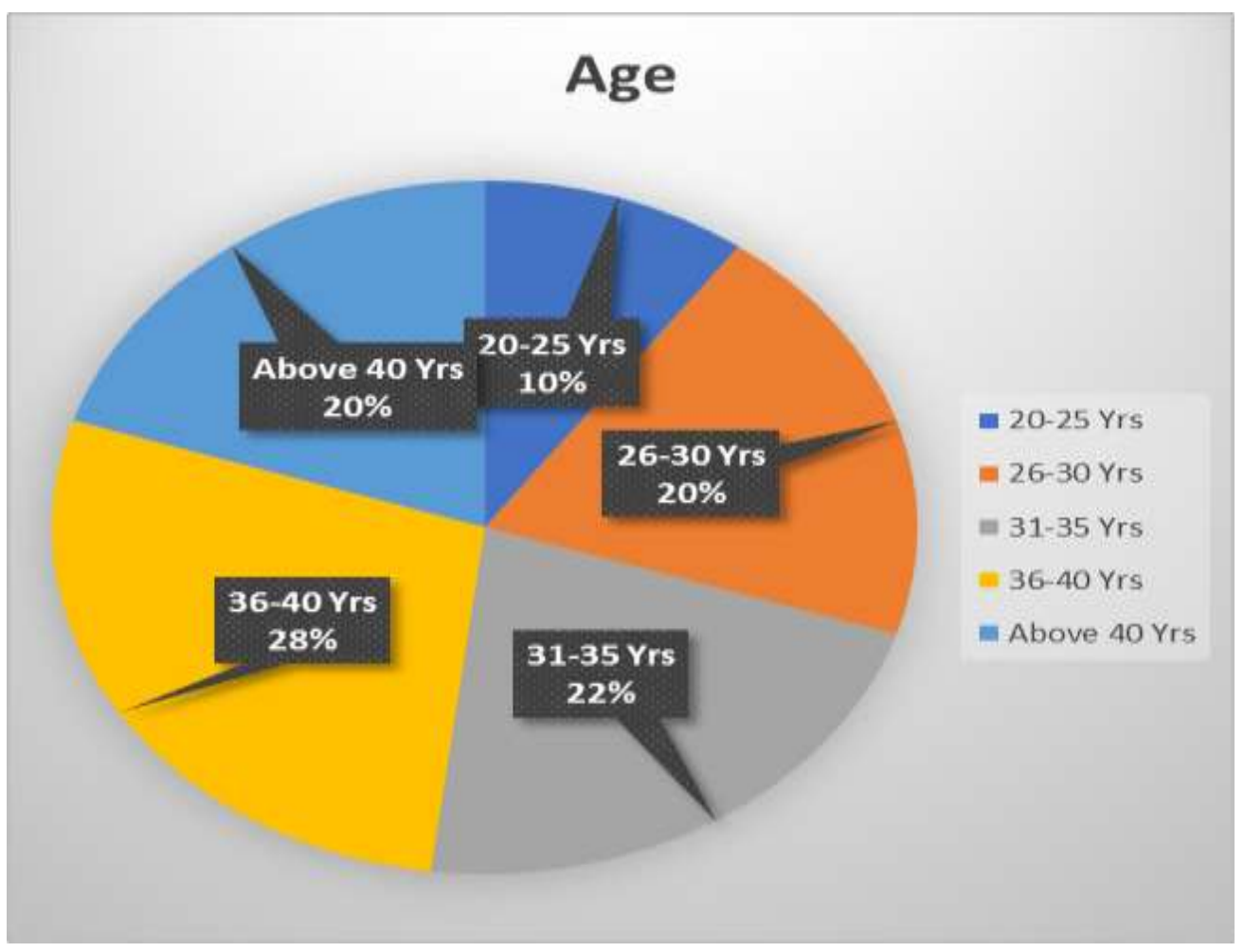

Figure 3: The Distribution of the respondents for Craft Art

The figure above showing the respondent by age distribution and the age group of 36-40 years shows the highest number of craftsmen on the market and the lowest age distribution of 20-25 years which has $10 \%$ of the selected sample of craftsmen. This means that the responses received shows that true information the researchers wanted and that the target age group for craft is achieved.

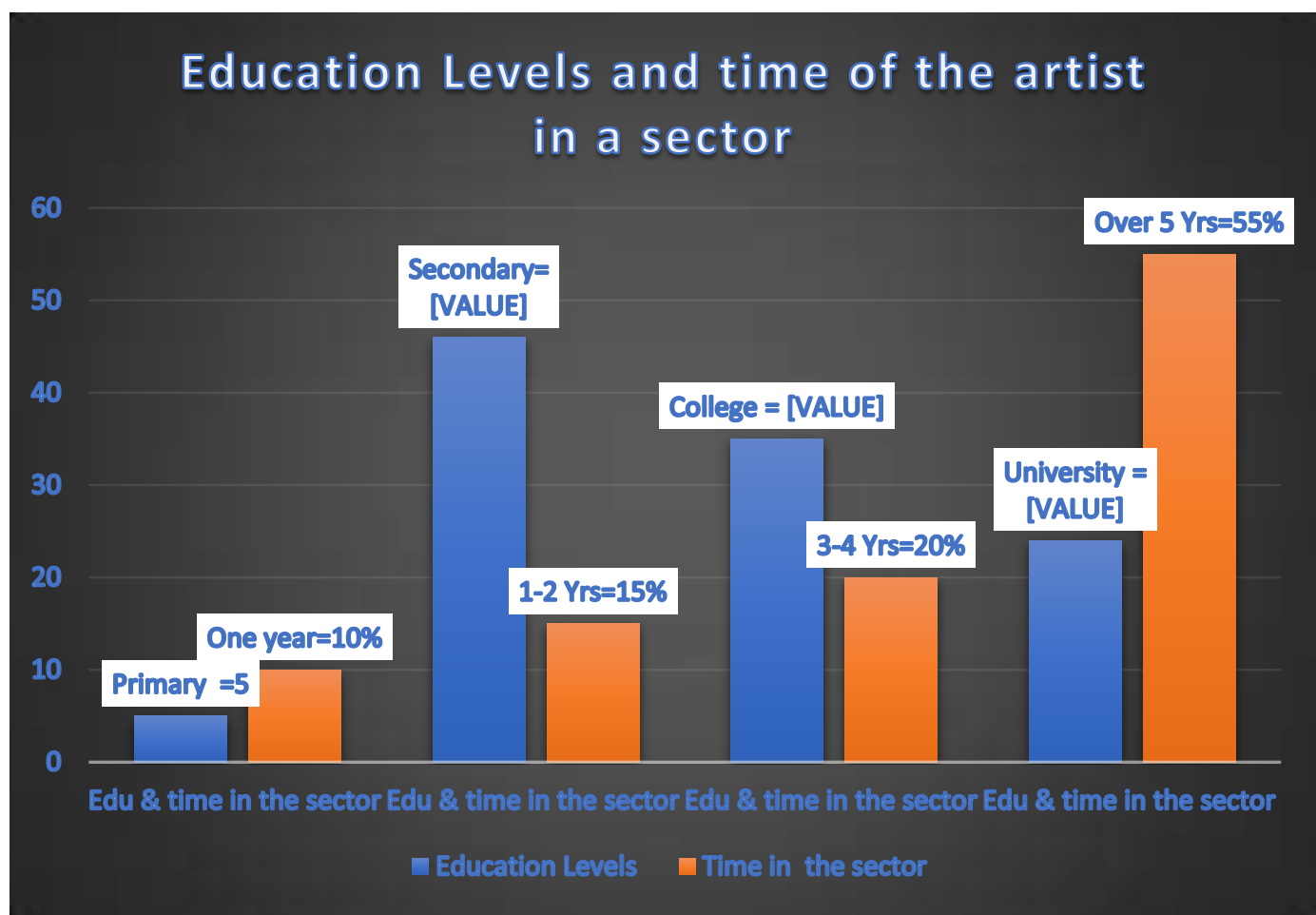

Figure 4: Education levels distribution and the time an artist have been in the industry

The education levels of the artist shows that a good number of them are educated and therefore information that is given is trustworthy and reliable. On the other hand 55\% shows that the artist have been in the business over five(5) years which guarantee experience and information obtained will reflect the true picture of the sector. 
International Journal of Advances in Scientific Research and Engineering (ijasre), Vol 5 (5), May-2019 4.2 VISUAL ART ANALYSIS

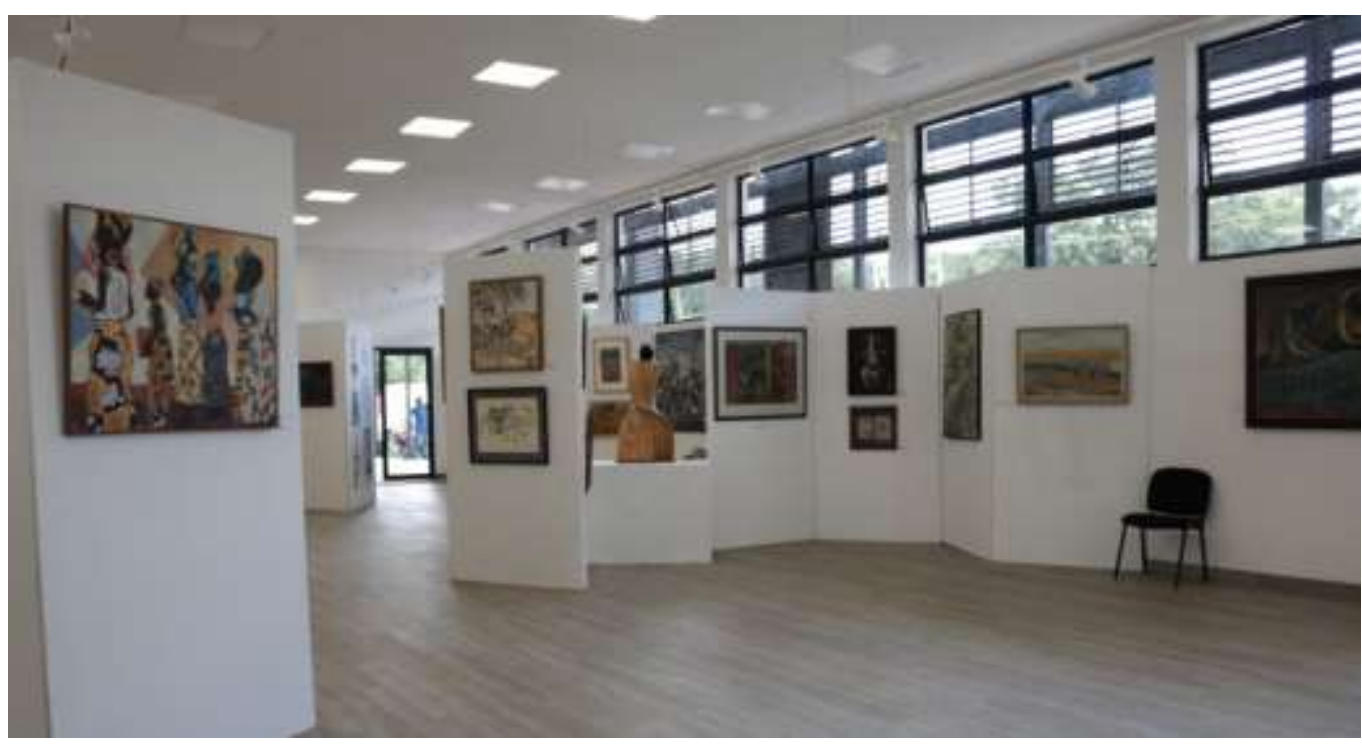

Figure 5: Visual arts in Lechwe Trust Gallery in Lusaka

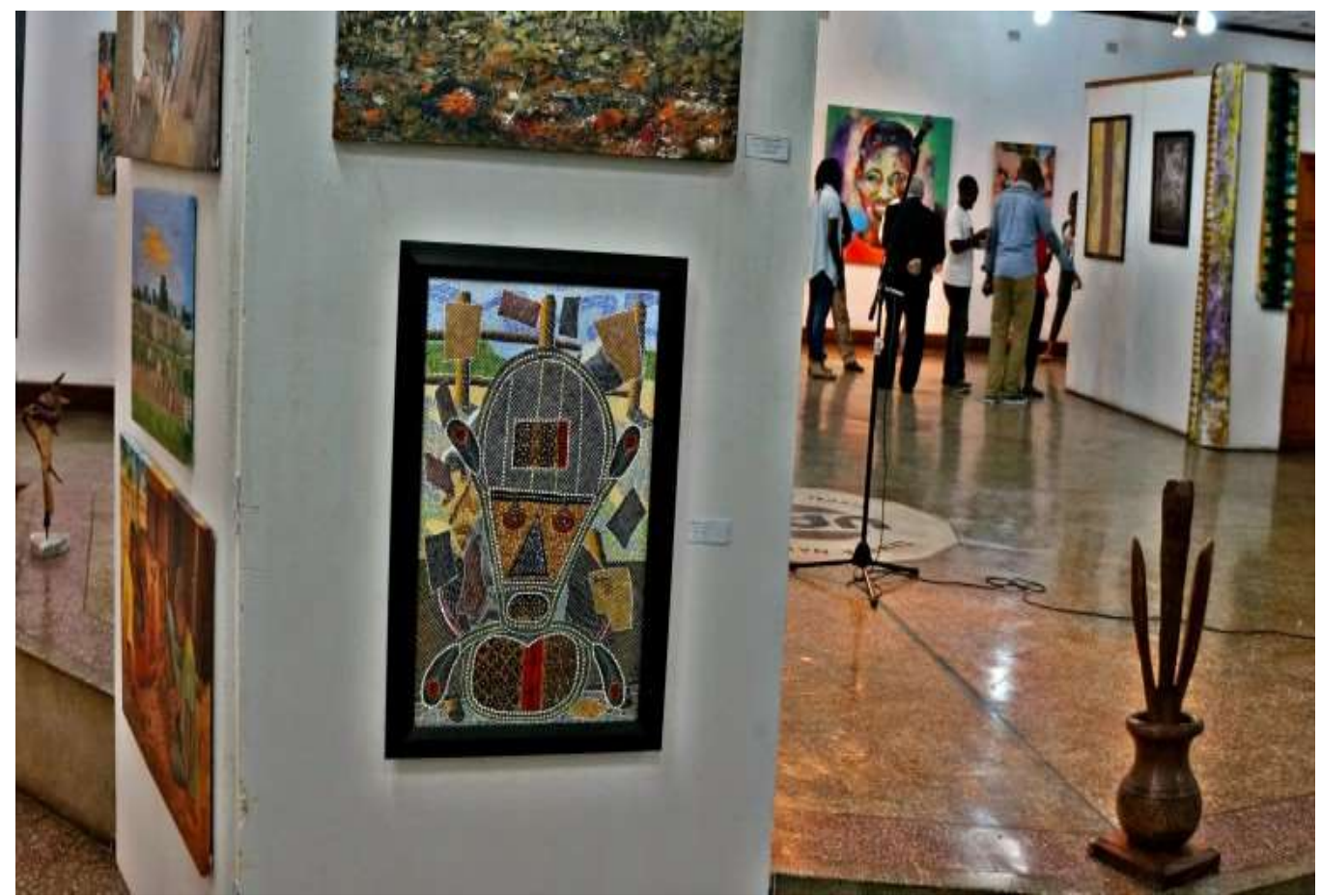

Figure 6: Visual art in Henry Tayali Gallery in Lusaka 
International Journal of Advances in Scientific Research and Engineering (ijasre), Vol 5 (5), May-2019

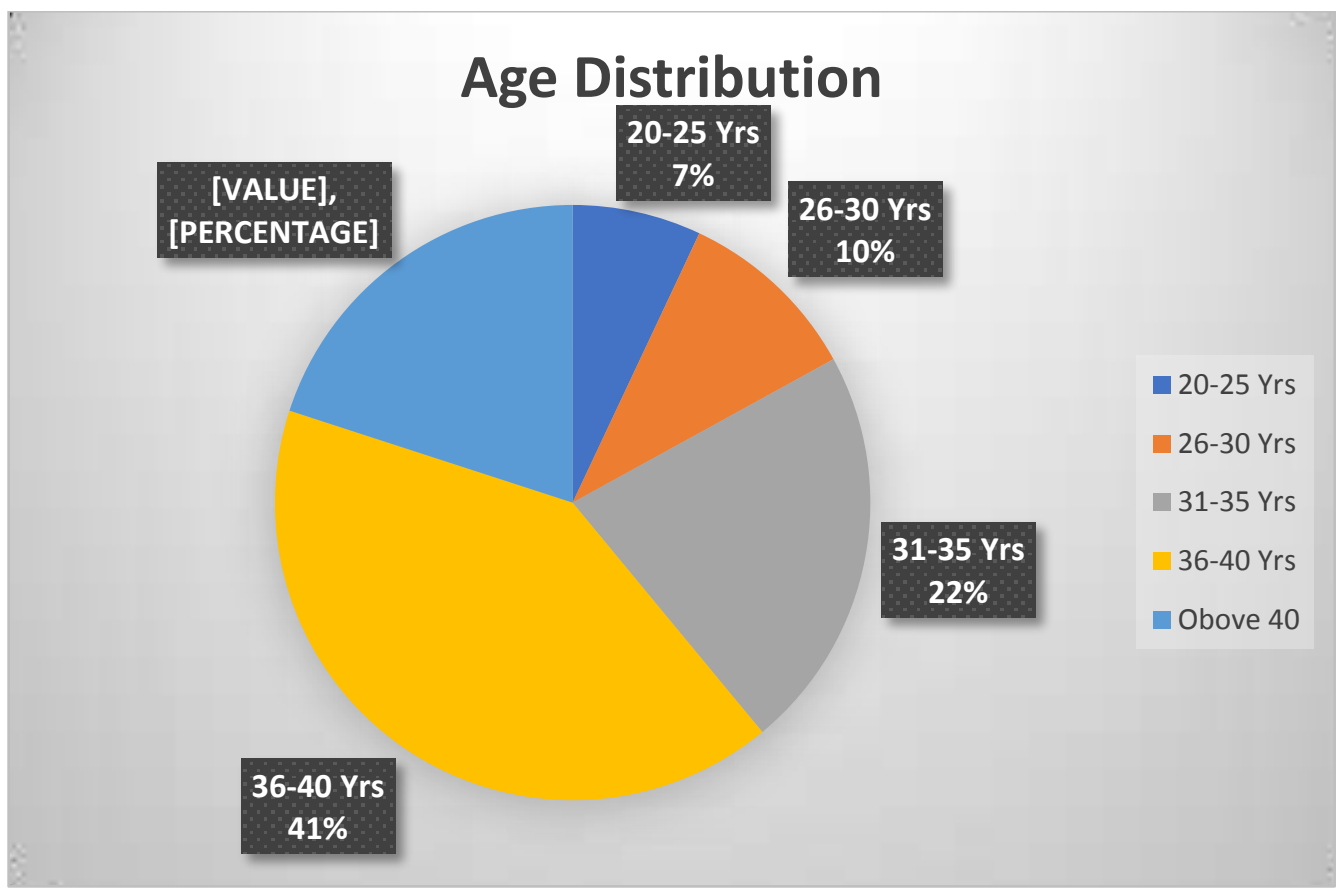

Graph 7: The distribution of age group from the selected sample of 100 Visual artist

The figure above showing the respondent by age distribution and the age group of 36-40 years shows the highest number of Visual artists on the market and the lowest age distribution of 20-25 years which has $7 \%$ of the selected sample of craftsmen. The researcher target group was 31 years to 40 years which means that target group was very presented

\subsection{MUSIC FESTIVALS}
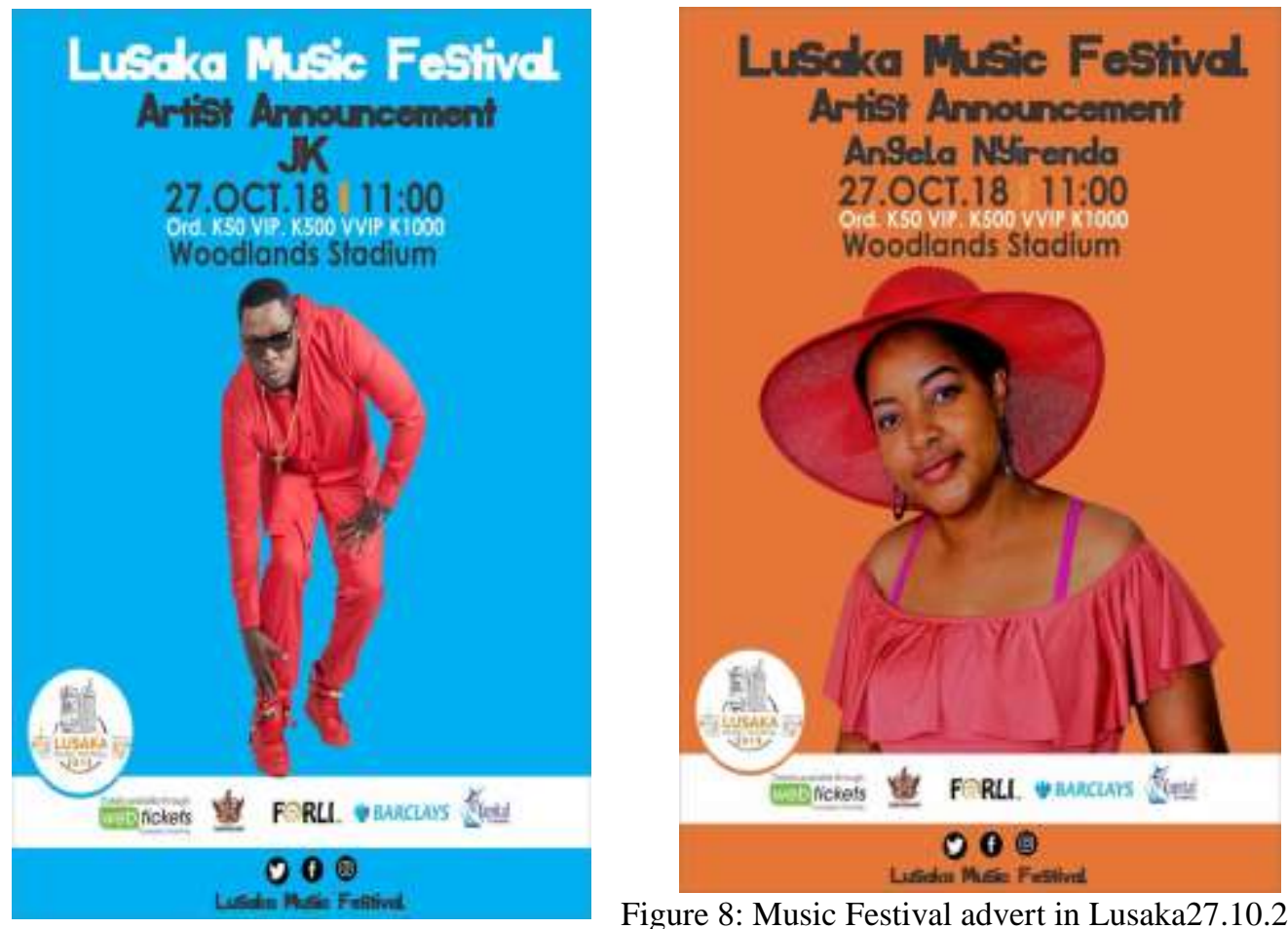

Figure 8: Music Festival advert in Lusaka27.10.2018 
The 2018 stanbic music festival in Lusaka attracted over Ten thousand music funs. However, there were other music festival in Lusaka which equally attracted over ten thousand fun across the country. The researchers assumed that the music festivals in Lusaka are organised at least once per quarter.

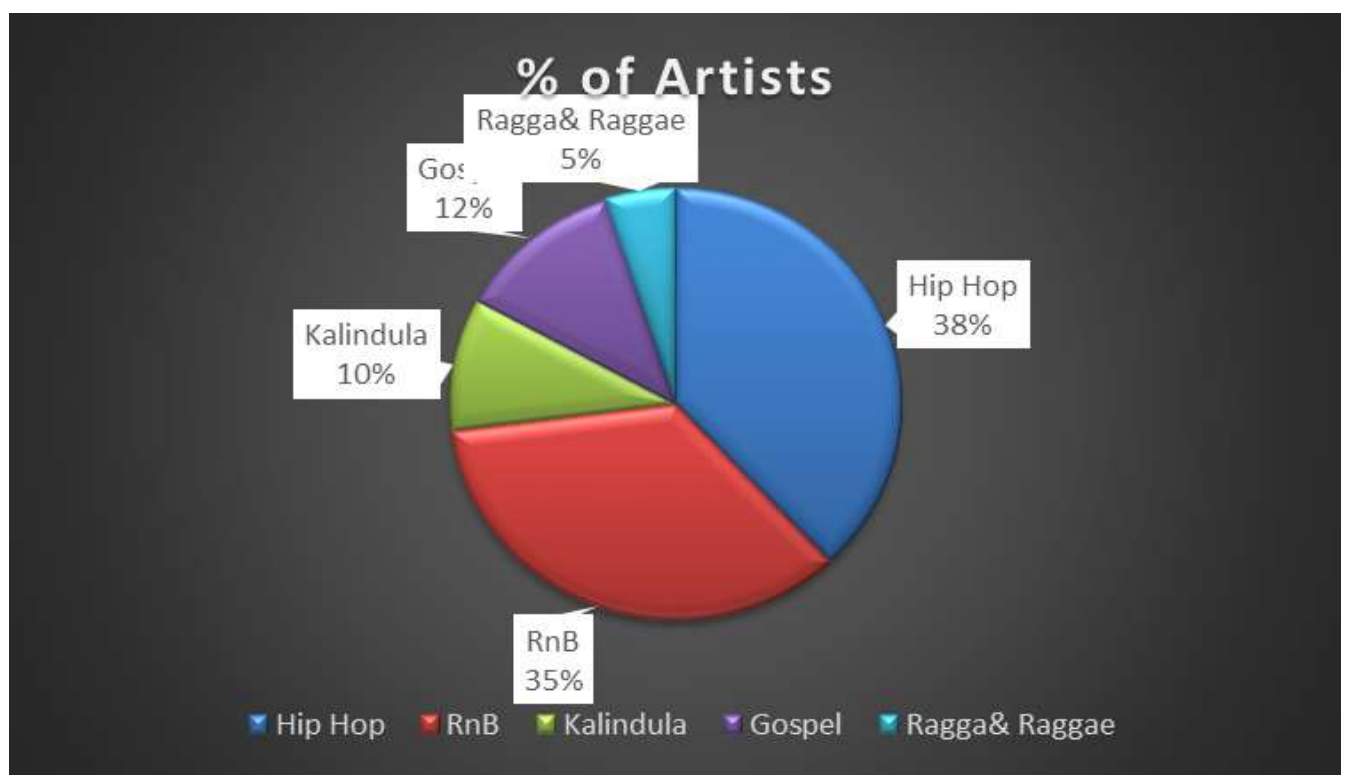

Figure 9: Distribution of Zambian music artsiest categories

The figure above showing the distribution of Music types and RnB as well as Hip Hop shows the highest number of Music artists on the market while Raga and Raggae is the lowest on the Zambian market. This is in line with the researcher target category of artists of RnB and HIP Hop to fully appreciate the sector.

4.1.1. Employment analysis

Table 3: Number of employees employed by selected sample of 100 craft art

\begin{tabular}{|l|r|r|r|}
\hline No. of Emplyees & Artist-Employers & total no. of employee & Cumulative Total \\
\hline 0 to 3 & 70 & 210 & 210 \\
\hline 4 to 8 & 24 & 144 & 354 \\
\hline Over- 8 & 6 & 48 & 402 \\
\hline
\end{tabular}

As expressed by $7^{\text {th }}$ national development plan and presidential pronouncement (refer to President Edgar Chagwa Lungu's to parliament for both 2017 and 2018), economies of most developed and developing depends and records high income and employments in subsector. Nollywood, Hollywood and Bollywood have already identified as key and major contributors to their country's GDP and accounts for over $16 \%$ thresholds.

Table 4: Contribution of Visual art to employment from selected sample

\begin{tabular}{|l|r|r|r|}
\hline No. of Emplyees & Artist-Employers & total no. of employee & Cumulative Total \\
\hline 0 to 3 & 80 & 240 & 240 \\
\hline 4 to 8 & 16 & 96 & 336 \\
\hline Over- 8 & 4 & 32 & 368 \\
\hline
\end{tabular}


International Journal of Advances in Scientific Research and Engineering (ijasre), Vol 5 (5), May-2019

Table 5: Contribution of Festival Music to employment in Lusaka District from selected sample

\begin{tabular}{|l|r|r|}
\hline Category of Music & employement proportion & Accumulation of employement \\
\hline Hip Hop & 1,988 & 1,988 \\
\hline RnB & 1,800 & 3,788 \\
\hline Kalindula & 300 & 4,088 \\
\hline Gospel & 167 & 4,255 \\
\hline Ragga\& Raggae & 43 & 4,298 \\
\hline
\end{tabular}

Table 6: Accumulation of employment for Craft, Visual and Music festivals in Lusaka

\begin{tabular}{|l|r|r|r|}
\hline CATEGORY OF ARTS & NO. OF PEOPLE EMPLOYED & ACCUMULATION OF EMPLOYEMENT \\
\hline CRAFT & 402 & 402 \\
\hline VISUAL ART & 368 & 770 \\
\hline MUSIC FESTIVAL & 4298 & 5068 \\
\hline
\end{tabular}

Zambia's labour force multiplied with the aid of 14 percent from 5 million in 2008 to 5.8 million in 2012 and the 2014 Labour Force Survey estimates the labour force at 6.3 million. Total employment grew by 11.3 percentage from 5.3 million in 2012 to 5.9 million in 2014, representing an employment-to-population ratio of 71.9 percent. About 4.9 million persons, representing eighty four percent of the employed, have been in the informal sector. Overall, the unemployment rate was 7.4 percentage of the complete labour force. Urban unemployment rate was 11.5 percent whilst rural unemployment charge was 4.2 percent. The youth unemployment remained one of the largest challenges. Of the 3,812,923 youths in the labour force, 400,810 were unemployed, representing a youth unemployment rate of 10.5 percent. The male early life unemployment fee was once higher at 12.2 percent than the lady early life unemployment rate at 9.1 percent. The rural childhood unemployment rate used to be 6.4 percent, in contrast to 15.2 city adolescence unemployment rate. From the analysis above and the result which have been given, it is evident that that creative industry in Zambia has created over 177, 000 jobs national wide presenting 3\% of total employment in the country. Visual arts, craft arts and music festival present $32.5 \%$ of the total industry employment translating into 57,525 country wide and Lusaka district stand at $8.5 \%$ translating to 4,602 jobs from 2014 to 2018 and it 2018 only the Visual arts, Craft and Musical Industry created over 1650 jobs ad indicated in the tables above.

\subsubsection{Government Revenue (Taxes) analysis}

Table 7: Government Revenue through taxes from 100 selected sample of craft art

\begin{tabular}{|l|r|r|r|r|r|}
\hline Tax Income & \multicolumn{1}{|c|}{ Artist-X } & Y -Mid value Monthly Inc of Sect & Yearly inc of se & Cumulative Total \\
\hline $0-500$ & 23 & 250 & $5,750.00$ & $69,000.00$ & $69,000.00$ \\
\hline $501-4,000$ & 66 & 2,250 & $148,500.00$ & $1,782,000.00$ & $1,851,000.00$ \\
\hline Over- 4000 & 11 & 4,000 & $44,000.00$ & $528,000.00$ & $2,379,000.00$ \\
\hline
\end{tabular}

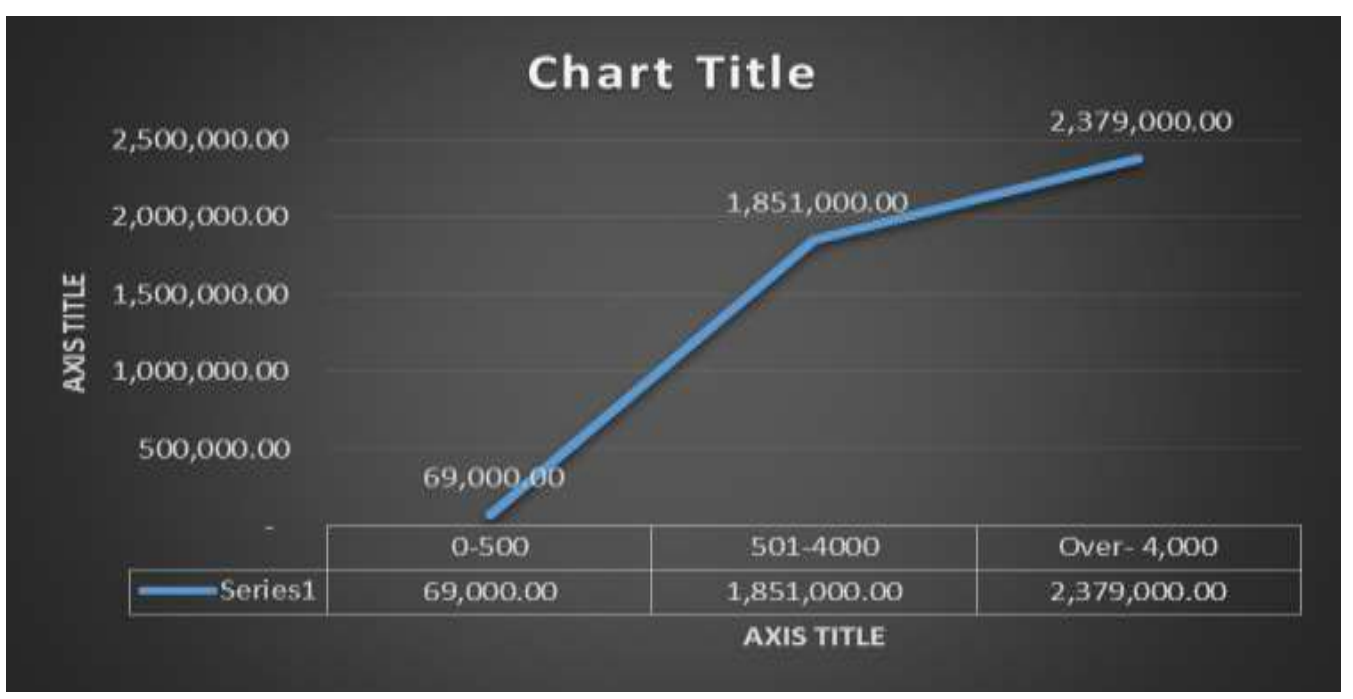

Graph 1: Government Income from 100 selected sample of Craft arts 
International Journal of Advances in Scientific Research and Engineering (ijasre), Vol 5 (5), May-2019

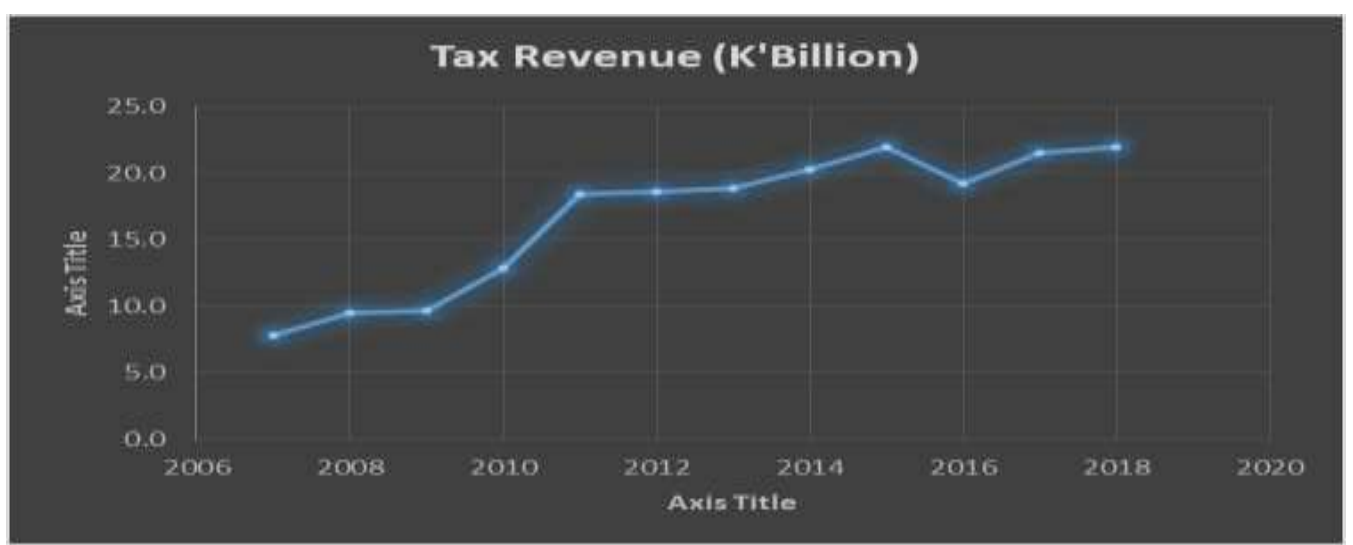

Graph 2: Trend of Government tax Revenue from 2007 - 2018

Zambia had one of the world's quickest developing economies for the ten years up to 2014, with real GDP growth averaging roughly 6.7\% per annum, although boom slowed all through the length 2015 to 2017, due to falling copper prices, reduced electricity generation, and depreciation of the kwacha. Zambia's lack of financial diversification and dependency on copper as its sole principal export makes it susceptible to fluctuations in the world commodities market and expenses became downward in 2015 due to declining demand from China; Zambia was once overtaken by the Democratic Republic of Congo as Africa's biggest copper producer. Zambia recorded a Government Budget deficit equal to 6.10 percentage of the country's Gross Domestic Product in 2017. Government Budget in Zambia averaged -2.53 percent of GDP from 1998 until 2017, accomplishing an all-time excessive of 18.30 percent of GDP in 2006 and a record low of -10.50 percent of GDP in 2016.

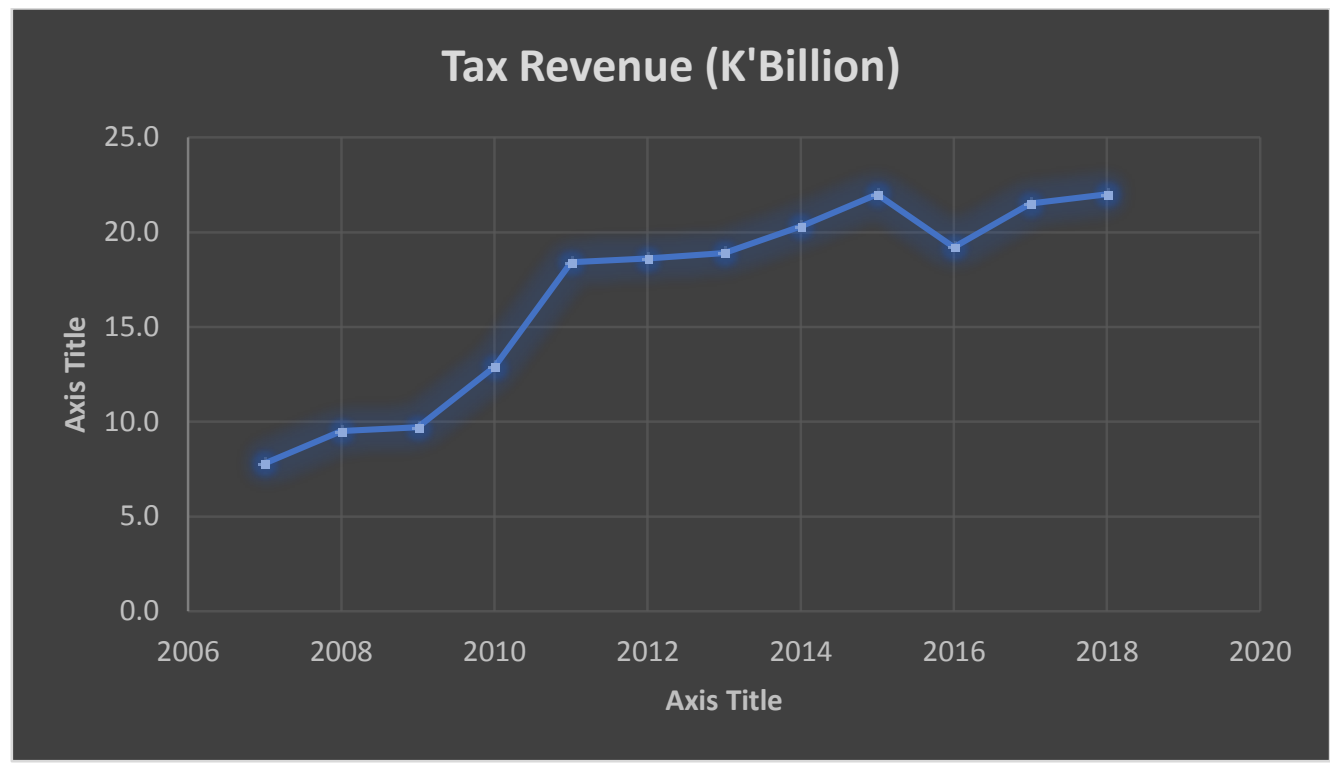

Graph 3: Government tax revenue as a \% of GDP 2006 - 2018

Table 8: Government Revenue from selected sample of 100 Visual artists

\begin{tabular}{|l|r|r|r|r|}
\hline Tax to government & No of Visual Artis & Monthly income & Yearly income & Cumulative Total \\
\hline $0-500$ & 15 & $7,500.00$ & $90,000.00$ & 90,000 \\
\hline $501-4000$ & 65 & $146,250.00$ & $1,755,000.00$ & $1,845,000$ \\
\hline Over 4000 & 20 & $8,000.00$ & $96,000.00$ & $1,941,000$ \\
\hline
\end{tabular}




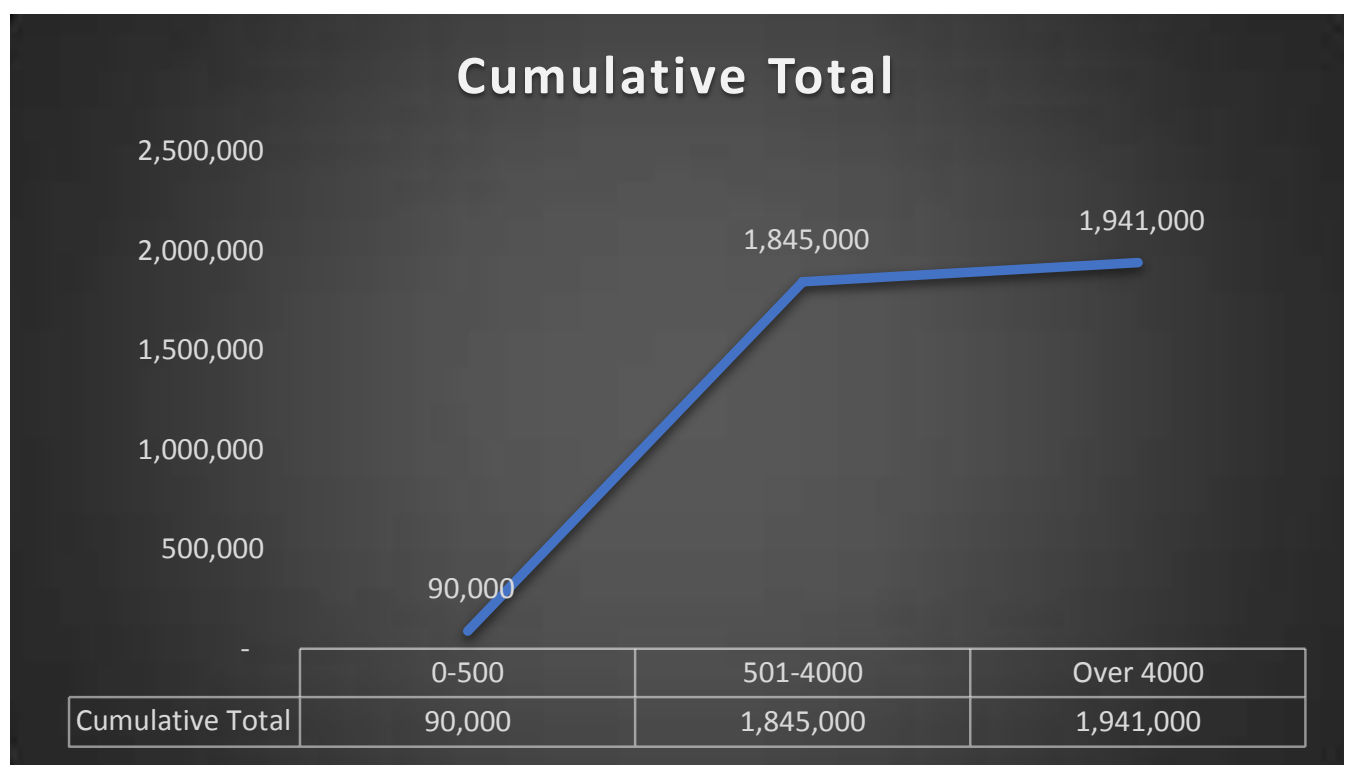

Graph 4: Cumulative total

Table 9: Government Income from Music Festivals

\begin{tabular}{|l|r|r|r|r|}
\hline Sector & \multicolumn{1}{|l|}{ Income } & Government Tax @ 16 & Government Income & Accumulative Income \\
\hline Beer & $1,600,000.00$ & $16 \%$ & $256,000.00$ & $256,000.00$ \\
\hline Drinks & $800,000.00$ & $16 \%$ & $128,000.00$ & $384,000.00$ \\
\hline Fuel & $19,272,000.00$ & $16 \%$ & $3,083,520.00$ & $3,467,520.00$ \\
\hline Transport & $3,200,000.00$ & $16 \%$ & $512,000.00$ & $3,979,520.00$ \\
\hline Food & $8,000,000.00$ & $16 \%$ & $1,280,000.00$ & $5,259,520.00$ \\
\hline Clothes & $12,000,000.00$ & $16 \%$ & $1,920,000.00$ & $7,179,520.00$ \\
\hline Hotel Bills & $8,000,000.00$ & $16 \%$ & $1,280,000.00$ & $8,459,520.00$ \\
\hline
\end{tabular}

\section{Table 5: Distribution of Government income from selected sample of Musical Festivals}

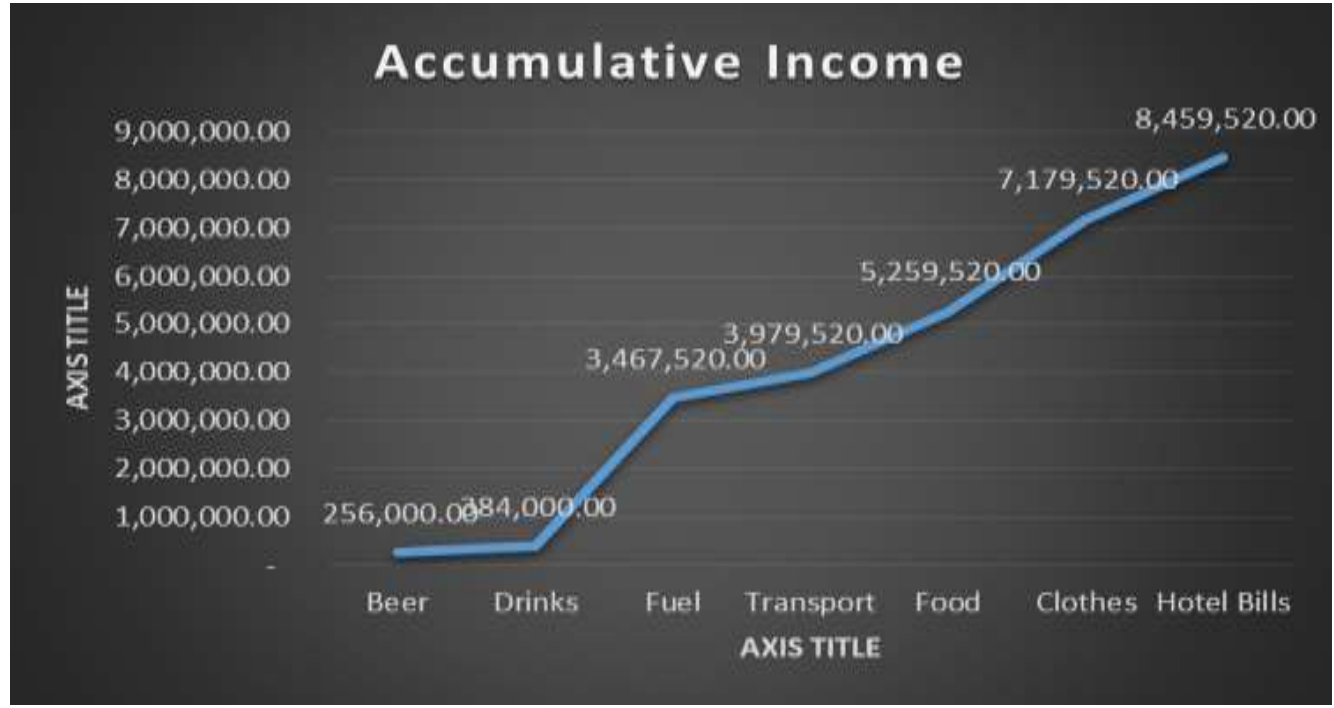

Zambia persisted to face slower growth in 2016. Tough global stipulations have mixed with domestic challenges including energy outages, tight liquidity, and constrained appetite for financial reform in the course of the first half of 2016. There is a want to look intently at methods to enhance income series so that economic recuperation will be expedited, boom itself can be made more inclusive to aid households get away from poverty, and to ensure that prosperity is higher shared in Zambia. There is a want to seem carefully at approaches to enhance income series so that financial recovery will be expedited, boom itself can be made greater inclusive to guide households escape from poverty, and to make sure that prosperity is higher shared in Zambia. The united states want to realise its intention of fiscal fitness, then greater home income collections are critical and need to work to 
enhance each tax policy and tax administration with the aid of enhancing tax administration which is to enhance a approach to expand tax compliance and scale up taxpayer targeted public training campaigns.

Rich growing international locations can significantly extend fiscal area for social safety and different socio-economic expenditures. Taxing herbal useful resource extracting industries allowed the Zambian government to improve their fiscal position and created the foundation for the enlargement of their social safety system. Developing countries frequently fighting to generate authority's revenues for social safety thru taxation and social security contributions. Tax authorities have a tendency to be weak and taxation lack transparency, whilst a particularly giant share of the populace is employed in the informal sector, making it challenging and expensive to gather social safety contribution or tax employees. This limits the ability to redistribute profits and to develop adequate social protection systems, inclusive of floors, to limit poverty and inequality.

\subsubsection{Household income analysis}

Table 10: The distribution of household income from selected sample of 100 craftsmen

\begin{tabular}{|l|r|r|r|r|}
\hline Income after tax & No. of Craftmen & Monthly income & Yearly Income & Cumulative Total \\
\hline $0-500$ & 40 & $20,000.00$ & $240,000.00$ & $240,000.00$ \\
\hline $1,501-2,500$ & 31 & $62,000.00$ & $744,000.00$ & $984,000.00$ \\
\hline $2,501-5,000$ & 19 & $71,250.00$ & $855,000.00$ & $1,839,000.00$ \\
\hline 0 ver 5,000 & 10 & $50,000.00$ & $600,000.00$ & $2,439,000.00$ \\
\hline
\end{tabular}

Table 11: The monthly and Yearly income for a selected sample of 100 craft men

\begin{tabular}{|l|r|r|r|r|r|}
\hline Income & Artist-X & Y -Mid value & Monthly Inc of Sect & Yearly inc of se & Cumulative Total \\
\hline $0-2000$ & 31 & 2,000 & $62,000.00$ & $744,000.00$ & $744,000.00$ \\
\hline $2,001-4,000$ & 46 & 3,000 & $138,000.00$ & $1,656,000.00$ & $2,400,000.00$ \\
\hline $4,001-8,000$ & 12 & 6,000 & $72,000.00$ & $864,000.00$ & $3,264,000.00$ \\
\hline $8,001-12,000$ & 6 & 10,000 & $60,000.00$ & $720,000.00$ & $3,984,000.00$ \\
\hline 0ver 12,000 & 5 & 12,000 & $60,000.00$ & $720,000.00$ & $4,704,000.00$ \\
\hline
\end{tabular}

Graph 6: The cumulative total of Income for 100 selected sample in the sector craft Sector

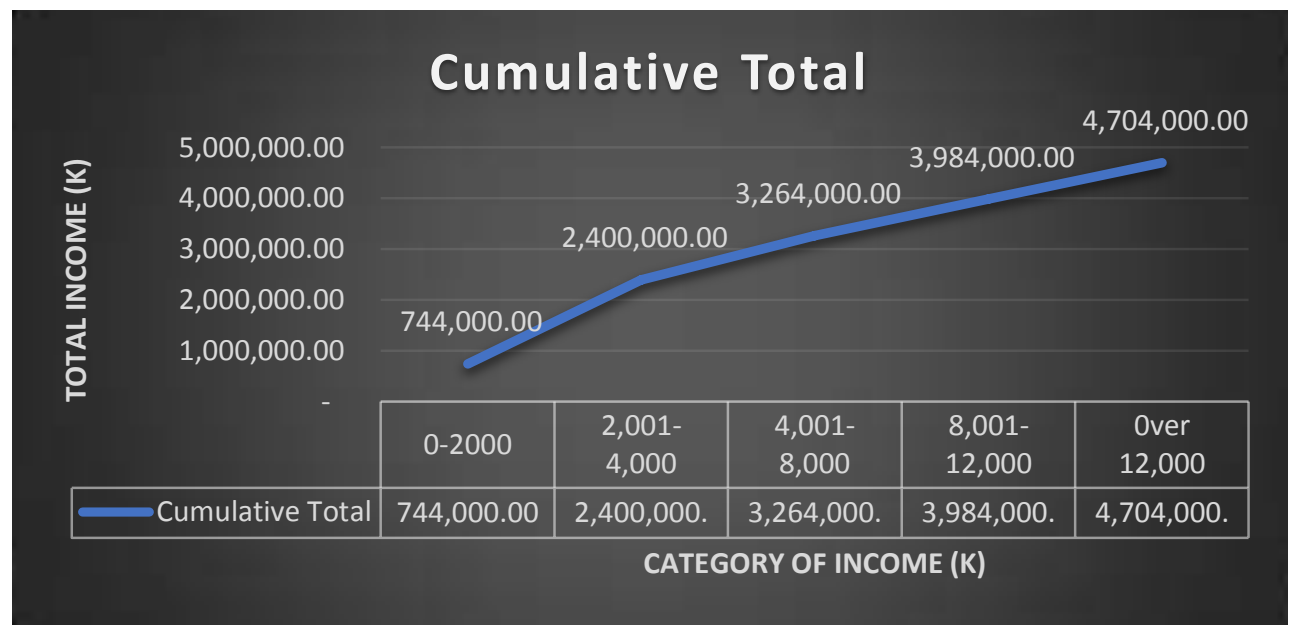

Graph 6: The cumulative total of Income for 100 selected sample in the sector craft Sector

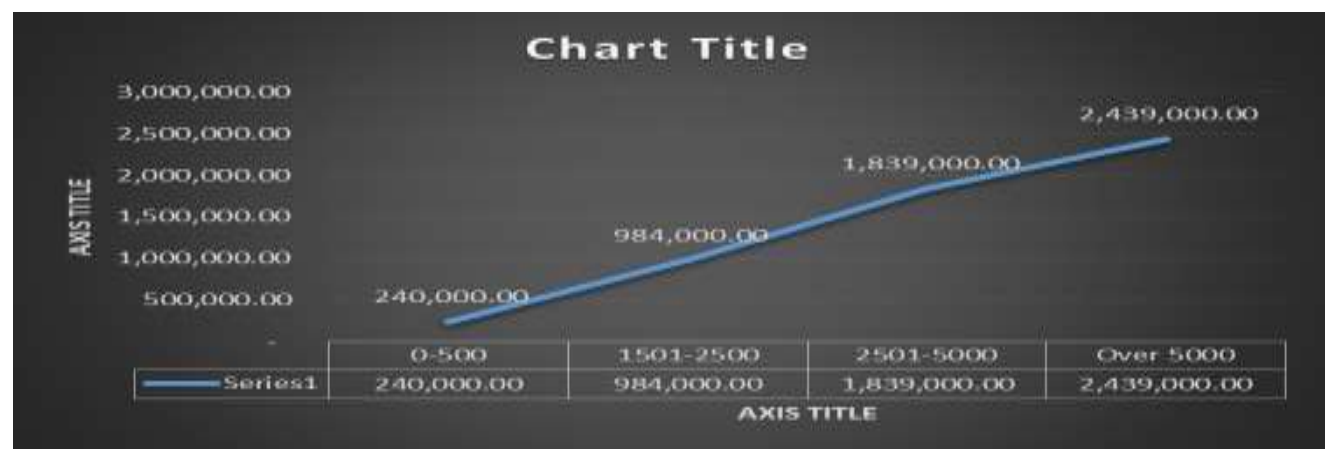

Graph 7: Cumulative Household income for selected sample of 100 craftsmen 
Table 12: The monthly and yearly income and Cumulative total for selected sample of 100 visual artist

\begin{tabular}{|l|r|r|r|r|}
\hline Income Category & Visual Artist & Monthly Income & Yearly Income & Cumulative Total \\
\hline $0-2000$ & 30 & 60,000 & 720,000 & 720,000 \\
\hline $2001-4000$ & 35 & 105,000 & $1,260,000$ & $1,980,000$ \\
\hline $4001-8000$ & 25 & 150,000 & $1,800,000$ & $3,780,000$ \\
\hline $8,001-12,000$ & 8 & 80,000 & 960,000 & $4,740,000$ \\
\hline Above 12,000 & 2 & 24,000 & 288,000 & $5,028,000$ \\
\hline
\end{tabular}

\section{Income Cumulative Total}

$2,500,000$

$2,000,000$

$1,845,000$

$1,941,000$

$1,500,000$

$1,000,000$

500,000

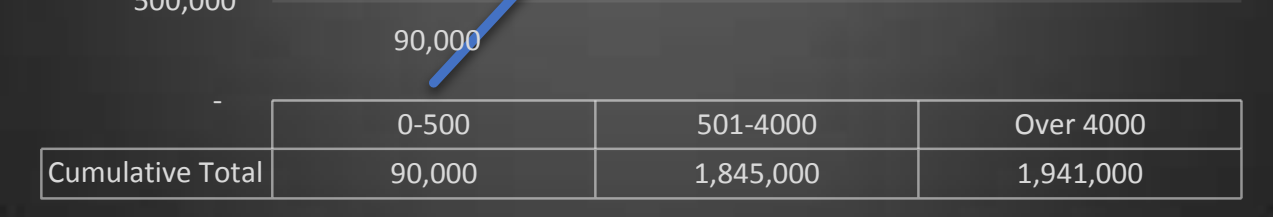

Graph 8: distribution of income from selected sample

Table 11: Household income of Visual Art selected sample

\begin{tabular}{|l|r|r|r|r|}
\hline Income after tax & Visual Artist & Monthy income & Annualy income & Cumulative total \\
\hline $0-500$ & 10 & 5,000 & 60,000 & 60,000 \\
\hline $501-1500$ & 64 & 64,000 & 768,000 & 828,000 \\
\hline $1501-4,000$ & 20 & 55,000 & 660,000 & $1,488,000$ \\
\hline Above 4000 & 6 & 2,400 & 28,800 & $1,516,800$ \\
\hline
\end{tabular}

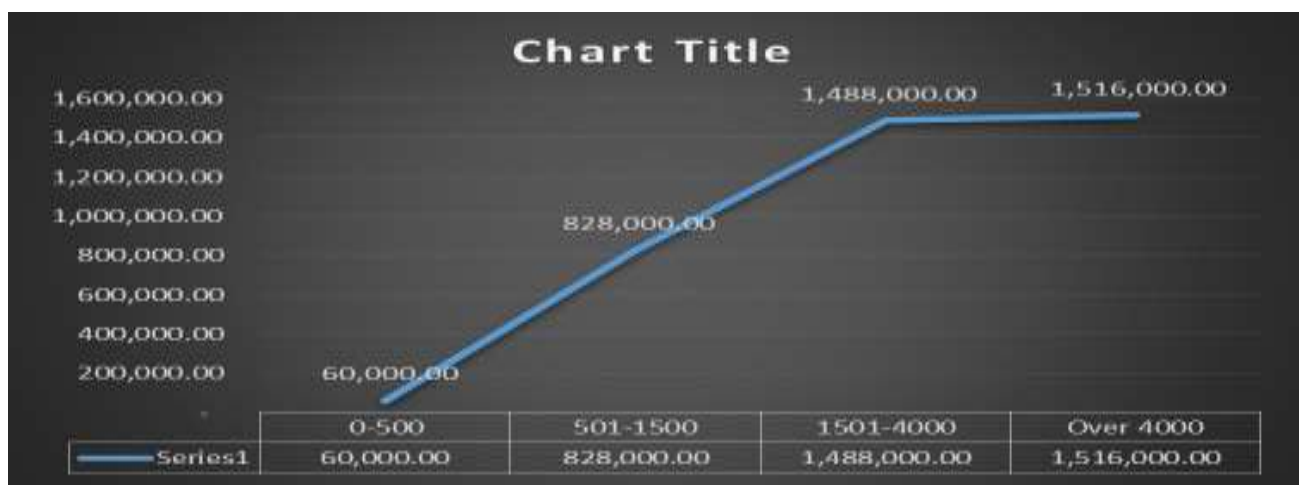

Graph 9: Distribution of cumulative Household income of Visual artist 
International Journal of Advances in Scientific Research and Engineering (ijasre), Vol 5 (5), May-2019

Table 12: The income realised from sale of tickets on Musical festivals

\begin{tabular}{|r|r|r|r|r|}
\hline Tickets Category(K) & Number of Tickets sold & quarterlyIncome & Annualy Income & Accumulative income \\
\hline 50 & 5,433 & 271,650 & $1,086,600$ & $1,086,600$ \\
\hline 500 & 3,367 & $1,683,500$ & $6,734,000$ & $7,820,600$ \\
\hline 1000 & 1,200 & $1,200,000$ & $4,800,000$ & $12,620,600$ \\
\hline
\end{tabular}

Table 13: Estimated Multiplier effect of Music Festivals on other Sector of economy

\begin{tabular}{|l|r|r|r|r|r|r|}
\hline $\begin{array}{l}\text { Tickets } \\
\text { Category(K) }\end{array}$ & $\begin{array}{l}\text { Number of } \\
\text { Funs }\end{array}$ & $\begin{array}{l}\text { Average no. } \\
\text { Consumed }\end{array}$ & $\begin{array}{l}\text { Average } \\
\text { price(K) }\end{array}$ & $\begin{array}{l}\text { Quarterly } \\
\text { Income }\end{array}$ & $\begin{array}{l}\text { Annual } \\
\text { Income }\end{array}$ & $\begin{array}{l}\text { Accumulative } \\
\text { Total }\end{array}$ \\
\hline Beer & 10,000 & 5 & 8 & 400,000 & $1,600,000$ & $1,600,000$ \\
\hline Drinks & 10,000 & 4 & 5 & 200,000 & 800,000 & $2,400,000$ \\
\hline Fuel & 10,000 & 30 & 16 & $4,818,000$ & $19,272,000$ & $21,672,000$ \\
\hline Transport(Bus or Tax) & 10,000 & 2 & 40 & 800,000 & $3,200,000$ & $24,872,000$ \\
\hline Food & 10,000 & 2 & 100 & $2,000,000$ & $8,000,000$ & $32,872,000$ \\
\hline clothes & 10,000 & 2 & 150 & $3,000,000$ & $12,000,000$ & $44,872,000$ \\
\hline Hotel bills & 5,000 & 1 & 400 & $2,000,000$ & $8,000,000$ & $52,872,000$ \\
\hline
\end{tabular}

Musical festival indicates that the sector creates employment to other artists and dances, and also creates employment for other sector and spill over. Demand and supply comes into play when there such events as indicated by the table above the value chain of musical festival creates economical and aesthetic values

\section{Accumulative Total}

$60,000,000$

$50,000,000$

$40,000,000$

$30,000,000$

$20,000,000$

$10,000,000$
$1,600,000 \quad 2,400,000$

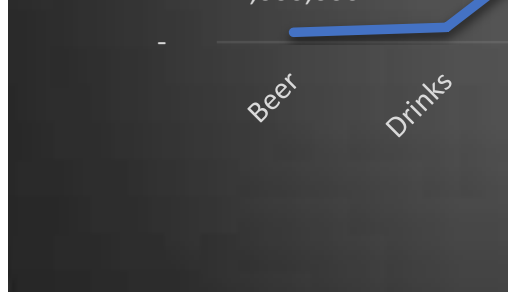

$52,872,000$

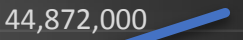

$21,672,00024,872,000$ $32,872,000$
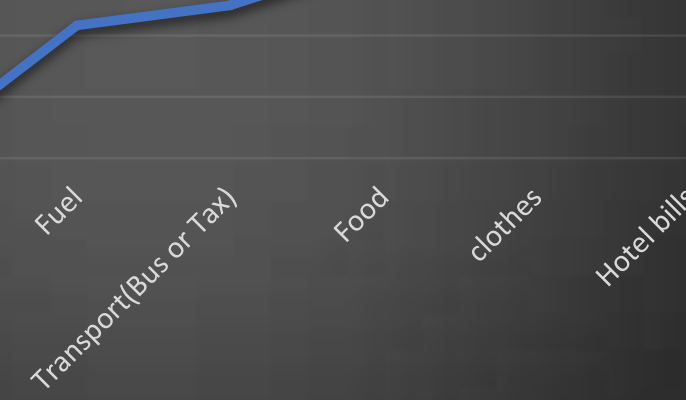

Graph 10: Accumulative total of multiplier effect of Musical festivals in Lusaka

The arts and culture are regarded as significant drivers of the economy and the city development. As the social and economic benefits has been illustrated in the literature review, craft and visual arts above, this have been successfully implanted by other countries and it has worked for them of which Zambia cannot be an exceptional.

Although the music festival may have small significant on the economy as a whole, it have great impact of the day to smooth running of the economy and high significant on the other sector of the economy. The sector has employed huge numbers which have not captured by neither central statistics office nor ministry of arts and tourism. From the graph above it is evident that this sector have potential to become one of the most promising sector which can be used as a tool for poverty reduction and , reduce youth un employment and complements government effort in employment creation and enabling environment for all.

The overall economy arts and culture (creative industry) accounts for $0.4 \%$ of the total GDP of Zambia, the sector has contributed above K 664,000,000 as purchase 


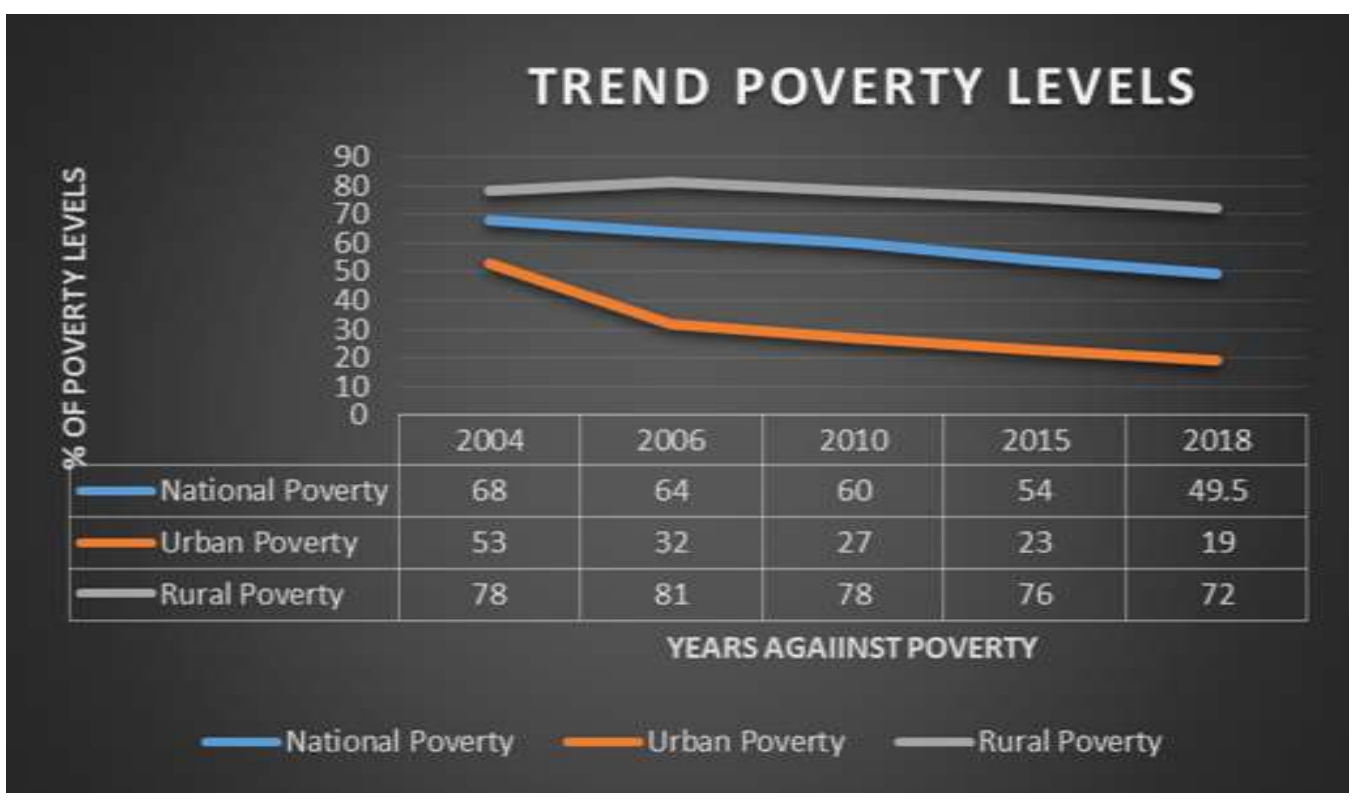

\section{Graph 11: The Trend of Poverty levels in Zambia 2004 - 2018}

The proportion distribution of the populace by using degree of poverty in 2015 showed that 40.8 percentage of the populace used to be extraordinarily negative whilst 13.6 percent used to be relatively poor. The share of the non-poor used to be 45.6 percent. With the 2015 projected country wide populace at 15.9 million, this intended that 8.5 million people lived in poverty, with 3.5 million of those living in severe poverty. It is clear that financial increase did now not translate into sizable poverty reduction, especially in rural areas. It has been observed that the pattern of financial boom in Zambia is fantastically unequal and has now not elevated the incomes of the poor rapidly ample to lift them out of poverty, mostly for three reasons. First, economic growth has historically been focused in capital-intensive industries such as construction, mining and transport. The secondly cause is related to the geographical aspect of growth, where urban areas have received extra than rural areas. The third cause is related to the structure of the economy; monetary increase in the Zambia has now not been associated with labour-intensive sectors in which the terrible tend to work. The researcher concludes the arts and culture going by household income has helped to reduce both rural and urban poverty levels in Zambia. As indicated, in 2018 the rural poverty levels stood at 72\% while the urban poverty levels has drastically reduces to $19 \%$ an indication that arts and culture industry has done much in urban areas than it has done in the rural areas.

Although on average income of most artists according to the data collected and analysis above shows between K2, 500.00 and K4, 000.00 below the JCTR monthly basket in Lusaka which is in the range of K 4,700.00 and K4, 900.00, we can conclude that indeed art have significant impact on the disposable income and able to cover the monthly food basket.

\subsubsection{Findings Research Question two: impact of Arts and Cultural Industry on the non-macro-economic variables.}

\subsubsection{Communities and social aspect of art and culture}

In an effort to analyse the contribution of arts and cultural industry in Zambia, the theoretical frame work of the study draws from the current social and economic challenges and how government can diversify the economy into this emerging industry by putting up macroeconomic policies which will protect the rights of artists, piracy and copying of artisan and cultural works so that the industry which is in its infancy stage can grow. In more specific, the theoretical framework to review the intervention of government to protect the industry and make it sustainable and also look at certain factors that could create a conducive environment for development of arts and cultural industry in Zambia which includes; political factors, social factors and economic factors. Cultural policies, cultural rights and sustainability are some of the indices that can be used to monitor and measure the development of the industry which is in line with the study carried out by Arterial Network 2014.

Art and cultural industry increases social capital and community cohesion. They are used as tools for human development (Costello 1998), it bring people together and unite them, and it keeps the traditions and practices of particular nation to be passed from generation to generation. Art and creative activities has been used as tool to preach peace during nation tension and political violence as well as tool for quicker communication to mass. Arts and culture builds social capital through boosting industrial abilities and motivate society to be civically engaged (Williams 1995). Arts strengthens social bonds, increase individuals healthy status and improve community physical health (Angus 1999), Arts improve people's psychological wellbeing through active participation in art and increase self-concept and sense of control over one's life (Guetzkow 2002) 


\subsubsection{Arts and cultural on education}

Arts education have been discussed in two major forums. To start with the Road Map for arts and education by UNESCO 2006 which focussed on the role arts education has among nations today and formulate the frame work of its application. This conference discussed many issues surrounding arts of education of whether arts are taught for art benefits or to support other subject or whether to develop skills of artist (UNESCO 2006). Other scholars believed that arts education is just a mare teaching subject or major tool with aim to improve and develop other subjects and areas of the study (Brewer 2002). Though it is said like that, art is a discipline on its own with greater values and benefits (Eisner 2004) and (Nussbaum 2010). The road map for art education brought out fundamental and purpose of art education of upholding the human right to education and cultural participation, develop individual capabilities, improve quality of education and promote expressive arts diversity (UNESCO 2006). Upholding human right to education and cultural diversity or cultural participation is in the same line with Article 27 of UDHR which declared that "All human being has the right to free participation in cultural community activities to enjoy arts and share in its scientific and technological nature and its economical and non-economic benefits (UN, 1948). Arts education has potential to drives these rights in providing quality education to young people and support artistic and cultural activities (UN 1989) and (O'Farrell 2010). According to UNESCO, 2006 the main aim of arts education is to develop capacities and development of oneself to sustain people's wellbeing (Sen 1999). The UNESCO, 2006 demonstrate how to achieve quality in education which is in support of the cognitive development. Art and culture has the unique characteristics of invaluable assets and development of peace (UNESCO 2000)

\subsubsection{Arts and culture on healthy.}

According to the Demographic and Health Surveys, the extent of deficiency disease hardly modified, with stunt flying, wasting and scrawny registering $40 \%, 5 \%$ and $25 \%$ in 1992 , compared to $40 \%, 6 \%$ and $5 \%$, severally, in 2013-14.

Captivating in arts action or essentially going to some sort of artistic activities seems to enhance physical wellbeing (Baklien 2000). This could be expected to some extent to its capacity to mitigate pressure. Likewise, art commitment extends and fortifies social bonds, which additionally enhances wellbeing (Ball and Keating 2002). On an increasingly physiological dimension, ( Johansson 1996) clarify: "we realize that the life form reacts with changes in the humoral sensory system - for instance, verbal articulation of horrendous insusceptible capacity, and is related with less therapeutic visits." Expressions of the human experience enhance mental prosperity. Going to expressions occasions might invigorate and calm pressure, thus prompting enhanced joy/life fulfillment. Dynamic support in expressions of the human experience leads, likewise, to enhanced self-idea and feeling of power over one's life. There are diverse reasons why this may be so. Loads of the narrative proof originates from network art and culture programs, some of which are outfitted towards poor, minimal or 'in danger' populaces (Williams 1995). This is upheld up by the little - and low quality - study information that do exist. To date, there has been no deliberate research between network art and culture programs working in various financial atmospheres to see whether such impacts seem, by all accounts, to be uniform. Art and culture activities of the human experience enhance aptitudes, social capital and inventiveness. Here again we need to recognize inactive and dynamic interest.

\subsubsection{Findings Research Question three: How can the Government of Republic of Zambia use arts and culture to enhance economic diversification in Lusaka district?}

\subsubsection{Arts and cultural policy of 2003 in Zambia}

In 2003, Zambia launched national cultural policy which started a way back in 1992 with the sole purpose of enhancing arts and culture sector in the country. in older to shape the direction and ensuring the effectiveness of this policy, the government through Department of arts and culture, the national arts council of Zambia, the Ministry of arts and tourism played a significant role and the formulation of cultural policy was an indication of government to foster development and promotion of Zambia s Rich diverse culture heritage and artistic skills possessed by its citizens.

Government has an important role to play in creating a climate in which the performing arts can flourish. This is vital not only from the point of view of economic development, but also from that of social development, of which the national culture is a prime component. As such it is very cardinal for the national policy document that is responsible for the arts and culture sector to assume an inclusive process during its preparation and where possible to even seek expert advice from foreign countries which may have greater experience in formulating cultural policies (Lamba 2007) 
Despite government recording a number of successes in the arts and cultural sector, however, it is evident that the sector still remains segmented. It is not uncommon to find some programmes and activities falling under different ministries, which makes the coordination of such programmes and funding to the sector quite cumbersome.

\subsubsection{Arts and cultural revised policy of 2009 in Zambia}

Since the launch of the current 2003 National Cultural Policy, the arts and cultural sector has undergone different phases include the revision exercise of the 2003 policy, which culminated in the 2009 draft National Cultural Policy which eventual placement of the arts and culture sector in the Ministry of Tourism and Arts in 2012 and the authoring of the Arts, Culture and Heritage Draft Act of 2013 to establish the Arts, Culture and Heritage Commission necessitate an urgent revision of the 2003 policy in order to make it more relevant and responsive to prevailing legislative, economy and social situations in the country(Lamba 2016)

The Government of Zambia has identified tourism, including arts and culture as one of the priority growth sectors of the national economy. The tourism sector holds the potential to be a major contributor to socioeconomic development as an important source of jobs, wealth, and competitiveness, particularly in the country's rural areas and holds major linkages to various other sectors of the economy (www.mota.gov.zm)

\section{CONCLUSIONS AND RECOMMENDATIONS}

The purpose of this chapter is to give the summary of the research finding and the extent to which the research objectives and questions were met and answered. It also highlights the recommendation and conclusion of finding of the evaluation of economic diversification of Zambian economy through arts and culture in Lusaka district. This analysis is important as it will help government to explore this sector and to be used to achieve the Zambia vision 2030 of a middle income country.

\subsection{Research Objective One: impact of Arts and Cultural Industry on the macro economic variables.}

\subsubsection{Employment}

The study may not bring out the contribution of music festivals to national GDP or Foreign exchange, but it has demonstrated its impact on other business which have been overlooked, the demand for other goods and services as shown in the table above. The employment in music festival sector can either be short term (contracts) and long term (permanent). The fact that music festival have multiplier effect on other sector of the economy, it means that arts and culture has the ability to create employment in these sectors indirect

\subsubsection{Government Revenue (Taxes)}

The ZRA need to continuously interact with the taxpayers in terms of taxpayer education, statistics dissemination and carrier provision. Tax payers must more and more comply on their personal by finding it simpler and efficient to deal with ZRA. This entails developing an environment that allows the taxpayers to comply with their duties besides necessarily going to ZRA offices. The government must make sure that all other departments that deal with taxpayers share this records with ZRA and vice versa so as to avoid taxpayers offering unique facts to ZRA and other government wings. The authorities must extend the network of Double Taxation Agreements to enable ZRA exchange information with countries the place multinationals running in Zambia does enterprise in and with. This is to assist ZRA have enough records to counter tax avoidance and evasion schemes like transfer pricing and skinny capitalization

\subsubsection{Household income}

In Zambia crafts arts, Visual arts and in few cases music are for the poorest household's only income generating activities (Joffe 2002) and the economic significance of arts and culture through job creation, income generation and foreign exchange through market participation and cultural tourism. The government have been launched to capacitate artists and crafters to generate income from their products and services. The Arts and Culture is potential tool to poverty alleviation and government through arts council of Zambia should focus on production and marketing of arts and culture products on internal and external markets: From the findings arts and culture has indeed increased household income for artists families and more importantly also on the people employed in this sector. A good number of the artists are able to manage the minimum household consumption per month by JCTR. 


\subsection{Research Objective two : the effects of Arts and cultural industry have on non-macroeconomic variable}

\subsubsection{Education}

Participating in dramatization and arts exercises enhances fulfilment in proficiency. Partaking in organized music exercises enhances accomplishment in maths. Schools that incorporate arts over the educational programs appears to be consistently higher average reading. The school performance contrasted with comparable schools that don't Participation in arts and culture activities increases cognitive capacities. This is likewise in accordance with the investigation directed by Art committee of England in the estimation of craftsmanship and culture to individuals and society.

All teachers are actors, the professional conduct of the teachers requires them to demonstrate and illustrate for the learning to be effective and impact the lives of the leaners. Social behaviours are shaped and consolidated by doing/acting, learners appreciate more when the lesson is demonstrated and done than just explaining.

The introduction of creative studies in schools, starting from lower levels will help in developing a cadre of future creative minds who will survive on the life skills and not the white collar job.

\subsubsection{Society and Community}

Arts and culture is expected to have impact on the rural development and rural financial inclusion and can reduce rural-urban migration and reduction in crimes in the country, promoting arts and culture in the country will strengthen region relationships and will enable the country to pass these tradition from one generation to the other.

It Improves people's feeling of having a place or connection with a network and Improves human capital, aptitudes and inventive capacities. This is likewise in accordance with the examination led by (Guetzkow 2002) in the article entitled "How the Arts Impact Communities".

As analysed above and literature review it is evident that various lessons come from the impact the arts have on the society. Songs shapes people's thoughts ,attitudes and way of doing things, refer to Lily T song entitled " Twakwaba umubi Pachalo Inkama Kubombesha”, our Nation motto “ One Zambia One nation”, other include Masha Moyo, Danny Kaya , P.K chishala , Glorious band and many more artist who have produced song for national unity, family unity and reduced tribalism

\subsubsection{Healthy}

Arts enhances wellbeing, mental prosperity, psychological working, innovative capacity and scholastic execution. Human expressions enhance singular wellbeing. Either captivating in imaginative movement or just going to some sort of aesthetic occasion seems to enhance physical wellbeing (Angus 1999). Workmanship and culture likewise fortifies social bonds, which additionally enhances wellbeing (Baklien 2000).

Arts and culture is expected to have multiplier effects on individual health, education and the industry expected to promote innovations. The industry will influence businesses positively and social cohesion, it will enable government to put extra effort in curbing piracy and start providing credit facilities to artist and cultural groups. The industry will promote music as a career in the country and will make art appreciate themselves. Art and culture puts the country on the world map and attracts visitor all over the world.

\subsection{Research Objective three: governments policy interventions on arts and culture for economic diversification}

Despite the government of republic of Zambia pronounce every year and document its policy direction in the national development plan, very little have been achieved. This is because the most interventions that are proposed are designed by technocrats and not industry players which has resulted in high levels of failure. The government has not enough financial and technical support in the area of arts and culture and most of it is under the National arts .however, it does not have meaning full budget which is only K100, 000.00 compared to K13 Million for tourism in 2018 budget. The following interventions have been put forward by various artist during data collection which includes:

i. There is a need for policy makers to come up with deliberate policy where government should have art work in offices to encourage artists and create market. 
ii. Government through art council of Zambia should come up with capacity building and supports artist financially and technical support. This can be achieved by enforcing all artist practising art works registered with the PACRA and have membership with National art council.

\subsubsection{Recommendations of Findings}

Though government of the republic of Zambia created a department of national arts council (NAC) by the act of parliament in 1994 and created a ministry of tourism and art to foster and promote art industry in Zambia, it has failed to live to its mandate of promoting the development of art. However, the department has managed to regulate the art industry (Lamba, 2007). The following are some of the policy recommendation

i. The government of republic of Zambia need fast economic diversification: it's imperative that the government absolutely exploits the country's resource endowments in arts and culture and diversifies economy from copper to this sector whereas increasing job opportunities.

ii. In this current social and economic challenges, the government should support a market full of self-employment, particularly among the youth and effectively participate in this market of self-employed opportunities that will arise from increased economic activities in sectors which will drive economic diversification.

iii. The government of republic of Zambia need to strengthen governance mechanisms and institutional capacities to accelerate attainment of a diversified and comprehensive economy

\subsection{Limitation of the Research}

Data on arts and culture production is scarce, and there is a lack of uniformity in indicators and data sets, which prevents comparison within and between periods

\subsubsection{Chapter Summary}

Zambia need to implement and strengthen the social security and protection of rights of artist in Zambia (Lamba, 2007). ). The government need to create internal and external markets for arts and culture product as a way of promoting this industry.

The arts and culture industry has demonstrated its ability and potential to contribute to employment, Government income, Household income and improve the wellbeing of the people and society. The industry can supplement Mining and Agriculture sectors in accelerate national development and help in achieving vision 2030 of the country being middle income nation.

\section{APPENDIX OF THE RESEARCH INSTRUMENT}

Complete this Survey Questionnaire and answer all Questions. I will use this survey to analyse Diversification of economy in arts and culture and its impact of macroeconomic variables. These macroeconomic variables include; Employment, GDP, Investment and national foreign exchange.

Thank you for your time.

Complete this Survey Questionnaire and answer all Questions. I will use this survey to analyse AN investigation of economic diversification of Zambian economy by using arts and culture industry: a case study of Lusaka district; these macroeconomic variables include; Employment, Household income and Government Revenue.

Thank you for your time.

\section{PERSONAL INFORMATION}

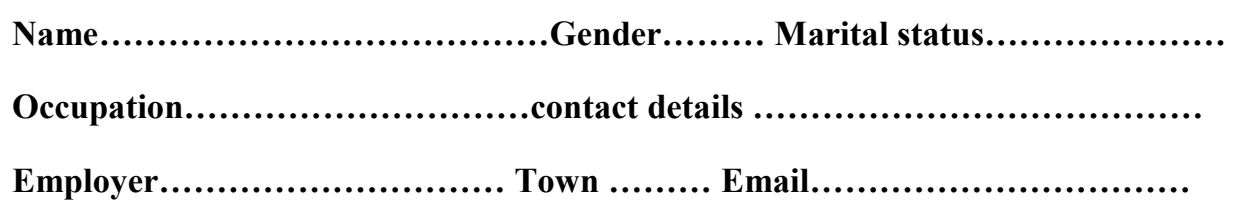


General Survey questionnaire for artists and cultural workers

(This is a survey being carried out in Lusaka District, please Tick one answer on each question or write down where necessary)

\section{PART A}

1 Position of Respondent

2 What is the age range (Please tick where appropriate)

\begin{tabular}{|l|l|l|l|l|l|}
\hline Age & $20-25$ Yrs & $26-30$ Yrs & $31-35$ Yrs & $36-40$ Yrs & Above 41 Yrs \\
\hline & & & & & \\
\hline
\end{tabular}

$\begin{array}{lllll}3 & \text { Gender } & \text { Male } & \text { [ ] } & \text { Female [ ] } \\ 4 & \text { Marital Status } & \text { Single } & \text { [ ] } & \text { Married }\end{array}$

$5 \quad$ Highest education level attained (please tick where appropriately)

$\begin{array}{lll}\text { Primary school [ ] } & \text { Secondary } & \text { [ ] } \\ \text { College [ ] } & \text { University } & \text { [ ] }\end{array}$

6 How long have you been an Artist/ employed/running the enterprise

Less than 1 year [ ] 1 year -2 years [ ]

3 years -4 years [ ] More than 5 years [ ]

3. What type of artistic or cultural activities are you engaged in?
Music
[ ] Craft art
[ ] Performance art
[]

Visual Art [ ] Video and Firm Production [ ]

Theatre [ ] Others

\section{PART B}

\section{EXAMINE OF FINANCIAL ASPECT}

I. Do you have any knowledge on financial record keeping? YES [ ] NO [ ]

2. Are you keeping some financial records on your business? YES [ ] NO [ ]

3. If yes which type of records,

- Daily [] 
International Journal of Advances in Scientific Research and Engineering (ijasre), Vol 5 (5), May-2019

- Weekly []

- Monthly

[ ]

4. How much monthly income do you earn per month?

\begin{tabular}{|l|l|}
\hline Income (ZMK) & Tick (Once) \\
\hline $0-2,000$ & \\
\hline $2,001-4,000$ & \\
\hline $4,000-8,000$ & \\
\hline $8,001-12,000$ & \\
\hline Above 12,000 & \\
\hline
\end{tabular}

7. Is your Business Registered? YES [ ] NO [ ]

5. If the answer is yes for question above, do you pay tax to Government?

$$
\text { YES [ ] NO [ }
$$

6. If yes, how much on Average per month?

\begin{tabular}{|l|l|}
\hline Income (ZMK) & Tick (Once) \\
\hline $0-500$ & \\
\hline $501-4,000$ & \\
\hline Above 4,000 & \\
\hline
\end{tabular}

7. Do you export your art works in the foreign market? YES [ ] NO [ ]

\section{PART C}

\section{PROVISION OF EMPLOYEMENT}

1. Have you employed anyone in the business? YES [ ] NO [ ]

3. If yes, how many workers tick in the table below?

\begin{tabular}{|l|l|}
\hline No. of employees & Tick (Once) \\
\hline $0-3$ & \\
\hline $4-8$ & \\
\hline Above 8 & \\
\hline
\end{tabular}

4. How much is the average salary per worker?

\begin{tabular}{|l|l|}
\hline Income (ZMK) & Tick (Once) \\
\hline $0-1500$ & \\
\hline $1501-2,500$ & \\
\hline $2,501-5,000$ & \\
\hline Above 5,000 & \\
\hline
\end{tabular}

5. How much is the house hold income after tax?

\begin{tabular}{|l|l|}
\hline Income (ZMK) & Tick (Once) \\
\hline $0-500$ & \\
\hline $501-1,500$ & \\
\hline $1,501-4,000$ & \\
\hline Above 4,000 & \\
\hline
\end{tabular}


7. Do you receive any incentives from the government? YES [ ] NO [ ]

8. How do you think you would improve your career as an artist?

- GRZ Sponsored Workshop

- Short Training []

- College [ ]

- Others.

\section{PART D}

\section{EDUCATION AND HEALTH ASPECTS}

1. Can arts and culture impact individual healthy? YES [ ] NO [ ]

If the answer is yes explain;

2. Can arts and culture influence education system? YES [ ] NO [ ]

If the answer is yes explain;

3. Do you think arts and cultural can influence communities or society?

YES [ ] NO [ ]

If the answer is yes, what do you think government can do?

4. Is the ministry of arts and tourism done enough in promoting this sector? YES [ ] NO [ ]

If the answer is NO, what advice can give to policy implementers?

\section{PART E}

5. Can arts and culture diversification create employment? YES [ ] NO [ ]

If the answer is yes explain;

6. Can arts and culture can stimulate rural development? YES [ ] NO [ ]

If the answer is yes explain; 
7. Do you think Government has done much to support arts and cultural business? YES [ ] NO []

If the answer is No, what do you think government can do?

8. Is there any law in Zambia which protect arts works? YES [ ] NO [ ]

If the answer is NO, what could be policies that government can formulate?

\section{REFERENCES}

1. Aleg, L. O. O. a. P. O., 2018. Macroeconomic Implications of Trade Diversification in Nigeria.

2. Art, A. G. \&. A. C. f. t., 2011. Arts and Creative Industries. A Historical Overview and an Australian Conversation.

3.Arts, A. f. t., 2003. Building Creative Economies, The Arts, Entrepreneurship, and

Sustainable Development in Appalachia, Washington: Monographe.

and Shagun Sabarwal, H. W., 2014. Quasi-Experimental Design and Methods, UNICEF,

4.Anscombe, F. J., 1973. Graphs in statistical analysis. The American Statistician, 27(1), 17-21.

5.Bryman, A. \& Bell, E. (2011) "Business Research Methods” 3rd edition, Oxford University Press.

6.Bushman, B. J. \&. W. G. L., 2001. Narrative impressions of literature: The availability bias and the corrective properties of meta-analytic approaches. Personality and Social Psychology Bulletin.

7.Cohen, R., 2017. how the nonprofit arts and culture industry impact the economy in your community, .

8.Elham Metwally, 2012. "Survey Research Methods", Journal of Organizational Change Management, Vol. 25 Issue: 1, pp.186188, https://doi.org/10.1108/09534811211199655

9. Union, E., 2012. Working group of eu member states experts (open method of coordination cultural and creative industries

10.Evans, G. a. S. P., 2004. Culture at the Heart of Regeneration. London, Department for Culture Media and Sport.

11.Ethridge, D., 2004. Research Methodology in Applied Economics. s.1. John Wiley \& Sons, p 24.

12.Fox, W. \&. B. M., 2007. A Guide to Managing Research. s.1. A Guide to Managing Research.

13.Guetzkow, J., 2002. How the Arts Impact Communitie, s.1.: Princeton University

14.Jellicoe, A., 1987. Community Plays and How to Put them on Methuen.

15.Jackson, S.L. (2009). Research Methods and Statistics: A Critical Thinking Approach 3rd edition. Belmont, CA: Wadsworth. 16.Kabanda, P., 2014. How the Performing Arts Can Advance Development and Human Progress. The Creative Wealth of Nations. 
17.Kaye, N., 1998. Art into Theatre Harwood Academic Publishers

18.Keating, M., Loftis, C., McMichael, J., \& Ridenhour, J. (2014). New dimensions of mobile data quality. Federal CASIC Workshops. Washington, DC

19.Kreuter, F., Mercer, A., and Hicks, W. (2014). Increasingfieldwork efficiency through prespecified appointments. Journal of Survey Statistics and Methodology, 2(2), 210-223

20.Kurkowski, K. (2013). Using internet and hand-held computers for data collection in Poland. Paper presented at the 5th International Workshop on Internet Survey and Survey Methodology. Daejon, Republic of Korea

21.Kothari, C., 2004. Research Methodology: Methods and Techniques. Jaipur, India: New Age International Publisher.

22.Mark White, D. M. E. P. a. K. P., 2014. Case Studies in Economic Diversification. Economic Diversity.

24.Mikic, H., 2009. Measuring the economic contribution of cultural industries. A review and Assessment of cultural Methodological Approaches, Issue UNESCO Institute of Statistics.

25.Nurs, K., 2006. Culture as the Fourth Pillar of Sustainable Development: Institute of International Relations University of the West Indies .

26.Onodugo Ifeanyi Chris, B. A. A. N. B. N., 2015. Diversification of the economy: A panacea for Nigerian economic development. Volume: 2( Issue: 5), pp. 477-483.

27.Rabih Abouchakra, C. N. M. M. R. N. a. R. S., 2008. Economic Diversification. The Road to Sustainable Development.

28.Reeves, C. R. \&. W. C. C., 1997. Genetic algorithms versus experimental methods. a case study. Paper presented at the 7th International Conference on Genetic Algorithms, East Lansing, MI, USA.

29.Saunders, M. L. P. T. A., 2007. Research Methods for Business Students, 4th edition Prentice Hall.

30.Shaw, G. E. a. P., 2006. Culture and Regeneration. Arts Research Digest

31.Suberu O. J., A. O. A. A. M. O. O.-B. A. E. D., 2015. Diversification of the Nigerian Economy towards a Sustainable Growth and International Journal of Economics, Finance and Management Science, Vol. 3, No. 2, pp. 107-114.

32.Tamsin Cox, d. a. D. A. G., 2015. Artworks Evaluation Literature Review, s.1.: dha \& the Institute for Cultural Practices, University of Manchester

33.Tim Callen, R. C. F. H. A. H. a. P. K., 2014. Economic Diversification in the GCC: The Past, the Present, and the Future 34.Kunin, r., 2013. Nanaimo arts and Culture Economic Impact Study, s.1.: s.n.

35.Lamba, p. f., 2007. The Impact of the 2003 National Cultural Policy, s.l.: s.n.

\section{About the Author}

Paul .B Ngosa, Zcas University of Zambian, published paper on Investigation of the economic diversification of the Zambian Economy Trough Arts and Culture: Case Study Lusaka District. 